LIBRARY

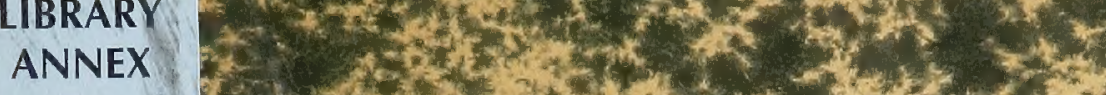

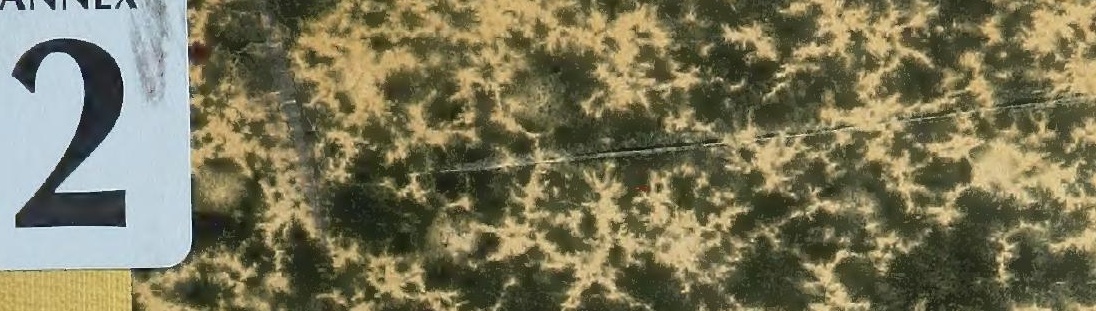

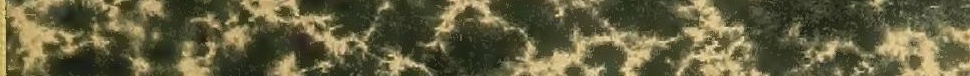

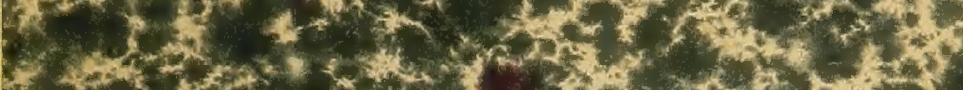

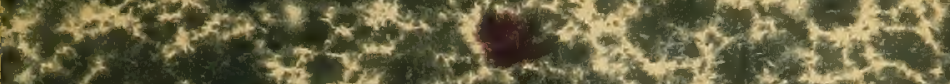

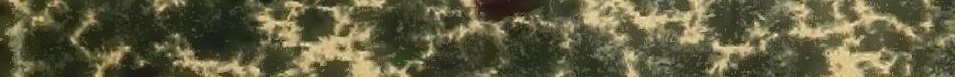

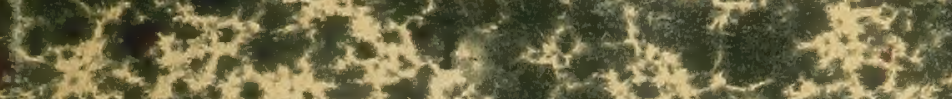

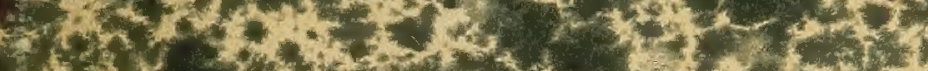

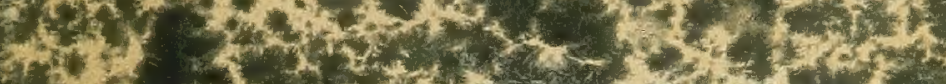

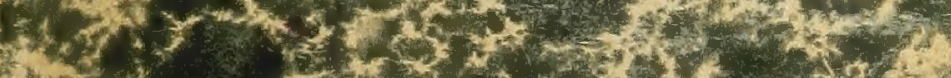

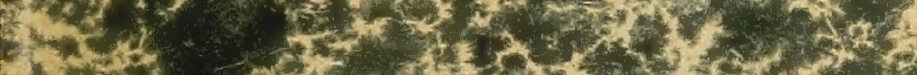

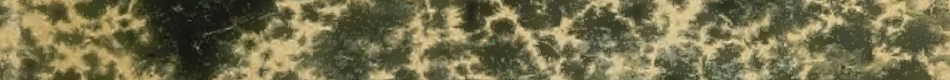

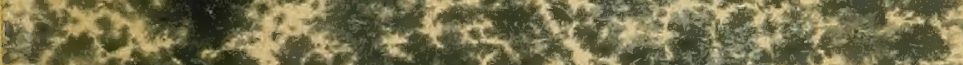

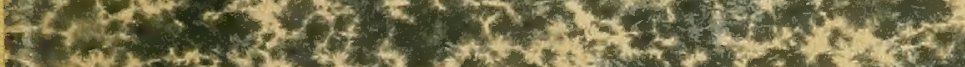

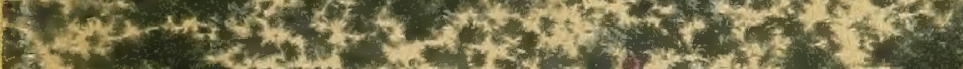

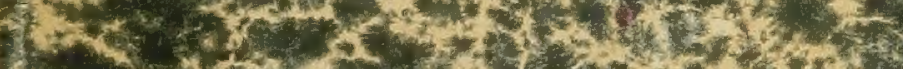

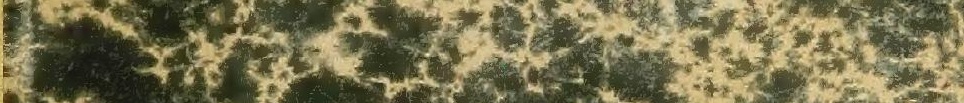

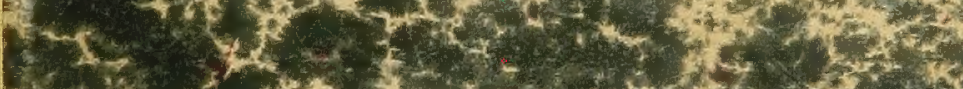

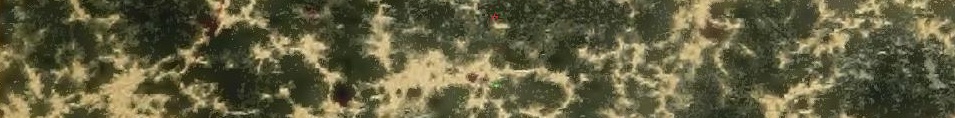
b.

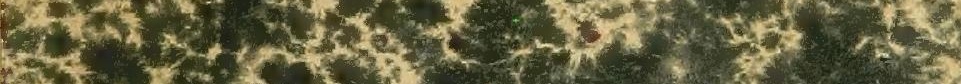

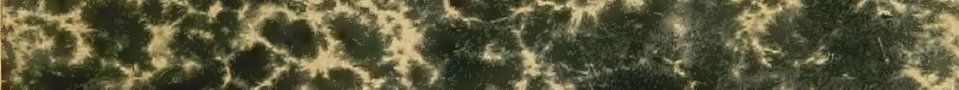

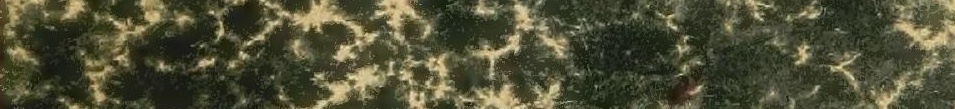

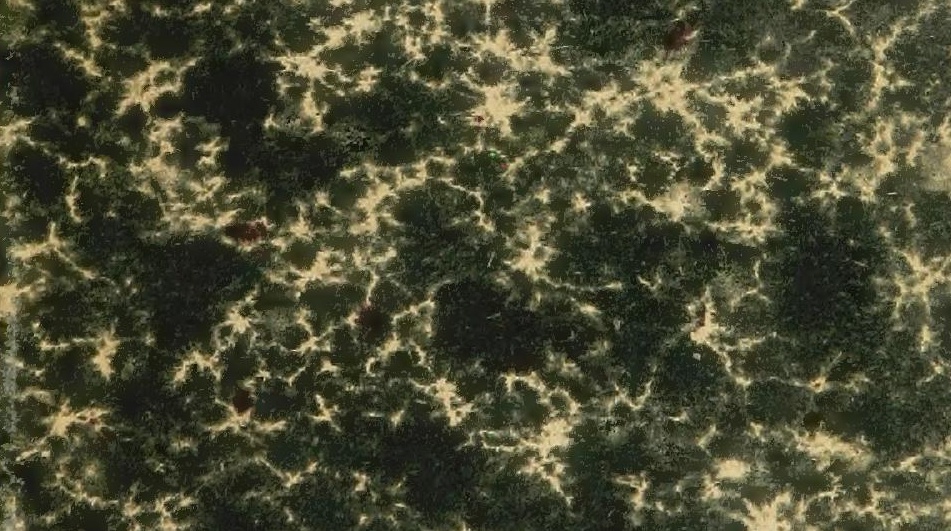




\section{Cornell Universite}

\section{Tibrary}

OF THE

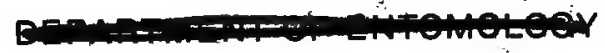

Nhew Work Ftate College of Afgriculture 


\section{QL 645 Cornell University Library}

Catalogue of New York reptiles and batra

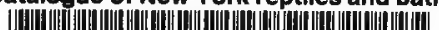

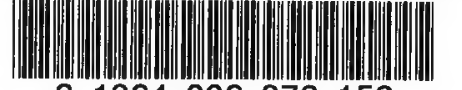

31924002872152 


\section{Cornell University Library}

The original of this book is in the Cornell University Library.

There are no known copyright restrictions in the United States on the use of the text. 




\title{
University of the State of New York
}

\section{New York State Museum}

Frederick.J. H. MerRili Director

\section{Bulletin 5I April I902}

\author{
OATALOGUE
}

or

\section{NEW YORK REPTILES AND BATRACHIANS}

BY

EDWIN C. ECKEL

AND

FREDERICK C. PAULMIER Ph.D.

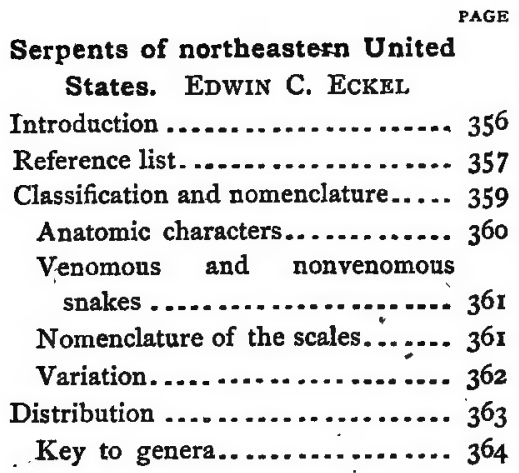

Distribution (continued)

PAGE

Color key to species............. 365

Specific descriptions Colubridae. .. $3^{66}$

Specific descriptions Crotalidae:-. 385

Lizards, tortoises and batrachians of New York. F. C. PaUlmier

Introduction ........................... $3^{89}$

Descriptions . . . . . . . . . . . . . . . . . 390

Plate I Metamorphoses of $\mathrm{Ba}$ trachia................. facing 396

Collecting and preparing .......... 407

Index ......................... 410

\section{ALBANY}

UNIVERSITY OF THE SPATE OF NEW YORK 


\title{
University of the State of New York
}

\author{
REGENTS \\ With years of election
}

1874 Anson Judv Upson L.H.D. D.D. LL.D.

Chancellor, Glens Falls

1892 William Croswell Doane D.D. LL.D.

Vice-Chancellor, Albany

I873 Martin I. Townsend M.A. LL.D. - - Troy

1877 Chauncey M. Depew LL.D. - _ - - New York

1877. Charles E. Fitch LL.B. M.A. L.H.D. - Rochester

I878 WhITELAW ReID M.A. LL.D. - - - New York

I88. William H. Watson M.A. LL.D. M.D. - Utica

I88I Henry E. TURner LL.D. - - - - - Lowville

${ }_{188}$ St Clair McKelway M.A. L.H.D. LL.D. D.C.L. Brooklyn

1885 Daniel BeAch Ph.D. LL.D. - _ - - - Watkins

1888 Carroll E. SMith LL.D. _ _ _ _ Syracuse

1890 Pliny T. Sexton LL.D. - $\quad$ - $\quad$ - Palmyra

I89o T. GUilford Smith M.A. C.E. LL.D. - - Buffalo

I893 L.ewis A. Stimson B.A. LL.D. M.D. - - New York 1895 Albert Vander Veer Ph.D. M.D. - - Albany 1895 Charles R. Skinner M.A. LL.D.

Superintendent of Public Instruction, ex officio 1897 Chester S. LoRd M.A. LL.D. - _ - - Brooklyn

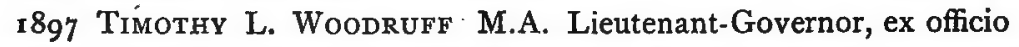
I899 John T. McDonough LL.B. LL.D. Secretary of State, ex officio I900 Thomas A. HENDRICK M.A. LL.D. - - - - - Rochester Igor Benjamin B. Odell JR LL.D. Governor, ex officio

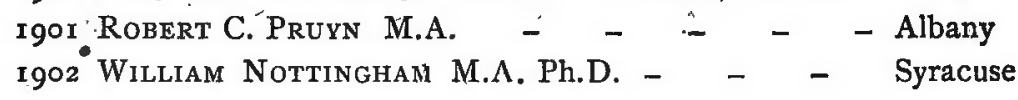

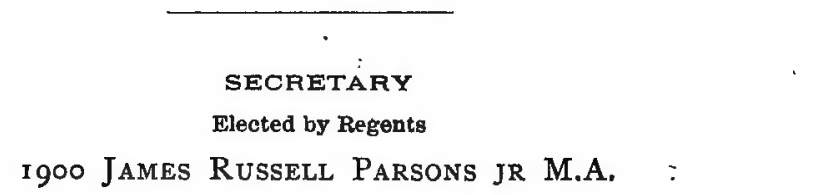

DIRECTORS OF DEPARTMENTS

I888 Melvil Dewey M.A, State Library and Home Education I8go James Russell Parsons jR M.A.

Administrative, College and High School Dep'ts

i8go Frederick J. H. Merrill Ph.D. State Museum 


\section{New York State Museum}

Frederick J. H. Merrili Director

\section{Bulletin 5I April Ig02}

\section{CATALOGUE OF \\ NEW YORK REPTILES AND BATRACHIANS}

\section{PREFACE}

Since the publication, by James E. De Kay, ${ }^{1}$ of his report on the zoology of New York in 1842, and by Spencer F. Baird, ${ }^{2}$ of the report on the serpents of New York state, great changes have been made in the nomenclature and classification of the reptiles and batrachians, and a number of new species and subspecies have been added to our fauna. The works named are, moreover, practically unobtainable, and no popular discussion of the subject is at present in print. The groups here treated are, in consequence, much less familiar to the general student than are the birds and mammals.

In view of these facts, it seemed desirable for the New York state museum, in pursuance of its definite policy of placing at the disposal of the citizens of this state trustworthy guides to the varions biologic groups, to issue a catalogne of the New York species of reptiles and batrachians as at present known, accompanied by descriptions suffcient to make it possible for nonspecialists to identify these species. At the request of the director, this work was undertaken by the authors of the two papers published in the present bulletin.

Information regarding the occurrence and distribution of the various species is much to be desired; and local faunal lists would be of much value in this connection, while specimens sent to the state museum will be identified. $\quad$ FrederioK J. H. MerRILL

${ }^{1}$ De Kay, James E. Zool. N. Y. v. 3, pt 3, 1842.

${ }^{2}$ Baird, Spencer F. Serpents of New York. N. Y. state cab. nat. hist. 7th an. rep't. 1854 


\title{
SERPENTS OF NORTHEASTERN UNITED STATES
}

\author{
BY EDWIN C. EOKEL
}

\section{INTRODUCTION}

The following catalogne was commenced with the intention of including only such species of serpents as have been found within the limits of New York state, together with such other species as could, from occurrences in adjoining states, be reasonably expected to occur here. A preliminary check list, prepared on that basis by the author, and published recently in the American naturatist, contained 25 species and subspecies. This list was notably imperfect, of which fact no one was more conscious than its anthor; but it was the first attempt to formulate such a catalogue since Baird's list of 1854 .

De Kay, in 1842, described 15 species of snakes as occurring in this state. To this list Gebhard added a sixteenth (S toreria occipitomaculata) in 1851, and a seventeenth (Sistrurus catenatus catenatus) in 1853. The present list names 19 species as inhabitants of New York state, one of these species however being represented by six subspecies. One additional species, (Coluber vulpinus) is added because of a single occurrence in Massachusetts; while the three remaining species have been found in Pennsylvania or New Jersey, but not in New York.

The total number of species and subspecies here described is 28 , and the catalogne, as now issued, includes every species and subspecies authentically recorded from that portion of the United States lying north of Maryland and east of Ohio. Two additions may have to be made to this list in the near future. It is probable that some more southern representative of $\mathrm{Osceola}$ doliata than O.d. triangula will be found to occur in New Jersey or Pennsylvania; while there is a possibility that some of the Ohio specimens (from Lake Erie) identified as $\mathrm{Natrix}$ fasciata erythrogaster may really prove to be of that subspecies.

As noted later in this bulletin, I am greatly indebted to Messrs H. D. Reed of Cornell university, and W. Seward Wallace of New York, for hitherto unpublished data which they have placed at 
my disposal. Mr Reed has further aided me by sending specimens from several localities in this state. It seems proper to poinit out here that $\mathrm{Mr}$ Wallace, in securing $\mathrm{Oycloph}$ is a estivus and Pityophis melanoleucus near Nyack N. Y., has made the first real addition to our local faunal list since 1853.

All the figures in this bulletin save those on pl. 1 are duplicates of those used in Cope's Crocodilians, lizards and snakes of North America, and are available for use here through the courtesy of the secretary of the United States national museum.

\section{Reference list}

The following list is not in any way complete, but it contrins all faunal lists, relating to the area under consideration, noticed by the author. Several of the more important general works on American herpetology have been added because of localities given in their texts; and, in addition, certain papers by Cope have been cited because of their bearing on the matter contained in the section on variation. For explnnation of asterisks, see p. 389.

The works are referred to in the bulletin by author and date.

* Abbott, c. C. '68. Catalogue of the vertebrate animals of New Jersey. Geol. N. J. p. 801-3.

* Allen, Glover M. '99. Notes on the reptiles and batrachians of Intervale, New Hampshire. Bost. soc. nat. hist. Proc. 29 : 63-75.

* Allen, J. A. '69. Catalogue of the reptiles and batrachians found in the vicinity of Springfield, Mass.: with notices of all the other species known to inhabit the state. Bcst. soc. nat. hist. Proc. 12 : 171-204.

Baird, Spencer, F. '54. On the serpents of New York; with a notice of a species not hitherto included in the fauna of the state. N. Y. state cab. nat. hist. 7th an. rep't, p. 95-124.

* Bicknell, E. P. '82. Review of the summer birds of a part of the Catskill mountains, with prefatory remarks on the faunal and floral features of the region. Linn. soc. N. Y. Trans. $1: 113-68$.

* Cope, Edward Drinker. "75. Check list of North American Batrachir and Reptilia. U. S. nat. mus. Bul. 1, p. 104.

92. Critical review of the characters and variations of the snakes of North America. U. S. nat. mus. Proc. $14: 589-694$.

'93. The color variations of the milk snake. Am. nat. $27: 1066-71$, pl. xxiv-xxivi.

'96. [Variations in Osceola doliata] Primary factors of organic evolution. N. Y. p. 29-41, fig. 2-11.

* _ 1900. Crocodilians, lizards and snakes of North America. U. S. nat. mus. Rep't. 1898. p. 153-1270, pl. 1-36.

* De Kay, James E. '42. Natural history of New York; Zoology of New York. v. 3, pt 3, Reptiles and amphibia. 2 7 . Alb. 
Ditmars, Raymond I. '96. Snakes found within fifty miles of New York. Linn. soc. N. Y. Abstract and proc. no. 8, p. 9-24.

Eckel, Edwin C. 1901. Snakes of New York: an annotated check list. Am. nat. 35 : 151-55.

* Fogg, B. F. '62. List of reptiles and amphibians found in the state of Maine. Portland soc. nat. hist. Proc. $1: 86$.

Gebhard, John, jr. '51. [Occurrence of Storeria occipitomaculata. in New York statc] N. Y. state cab. nat. hist. 4th an. rep't, p. 23.

-_ '53. [Occurrence of the Massasauga, Crotal o p-h or us ter g e minus in New York state] N. Y. state cab. nat. hist. 6th an. rep't, p. 22.

* Holbrook, J. E. '42. North American herpetology. 5 v. Philadelphia 1842.

* Hough, Franklin B. '52. Catalogue of reptiles and fishes, from St Lawrence county, procured for the state cabinet of natural history by Franklin B. Hough. N. Y. state cab. nat. hist. 5th an. rep't, p. 23-28.

* Jordan, David S. '99. Manual of the vertebrate animals of the northern United States. Chicrgo. 1899.

* Kirtland, Jared P. '38. Report on the zoology of Ohio. O. geol. sur. 2d an. rep't. p. 155-200.

* Iinsley, James H. '44. Catalogue of the reptiles of Connecticut. Am. jour. sci. 1st ser. $46: 37-51$.

* Macauley, James. '29. [Serpents of New York state] Natura], civil and' statistical history of the state of New York, by James Macauley. 3 v. 0 . $1: 441,513-17$.

* MacKay, A. H. '96. Reptiles and batrachians of Nova Scotia. Nova Scotian inst. of sci. Proc. ix : xli-xliii.

* Mearns, Edgar A. '98. A study of the vertebrate fauna of the Hudson highlands. Am. mus. nat. hist. Bul, 10 : 303-52.

_- 99. Notes on the mammals of the Catskill mountains, New York, with general remarks on the faune and flora of the region. U. S. nat. mus. Proc. 21 : 341-60.

* Morse, Max. 1901. Ohio reptiles in the Ohio state university zoological museum. Ohio naturalist. $1: 126-28$.

* Nelson, Julius. '90. Descriptive catalogue of the vertebrates of New Jersey. State geol. N. J. Final rep't. v. 2, pt 1, p. 643-48.

Putnam, F. W. '65. [On the species of the genus $\mathbf{E}$ u t a enia B.\&G.] Bost. soc. nat. hist. Proc. $9: 60^{\circ}-62$.

'66. [Occurrence of worm snake in New Engiand] Essex inst. Proc. iv : lx xxiii-lxxxiv.

* Reed, H. D. 1901. Notes on the snakes of the vicinity of Ithaca, N. Y. (Manuscript placed at my disposal by the author)

* Smith, David S. C. H. '33. [Catalogue of the] Reptilia [found in Massachusetts] Rep't geol. Mass. 1833. p. 552, 2d ed. 1835, p. 534.

* Smith, W. H. '82. Report on the reptiles and amphibians of Ohio. O. geol. sur. Rep't. v. 4. Zoology and botauy, p. 629-734. 
Stejneger, Leonhard. '95. Poisonous snakes of North America. U. S. nat. mus. Rep't. 1893 . p. $337-487$, pl. 1-19.

1901. Eckel's Snakes of New York. Am. nat. $35: 428$.

* Storer, D. H. ' 39 . Reports on the fishes, reptiles and birds of Massachusetts. Bost. p. 221-34.

* Thompson, Zadock. ' 42 . [Serpents of Vermont] History of Vermont, natural, civil and statistical, by Zadock Thompson. p. 115-19.

* Verrill, A. E. '65. Catalogue of the reptiles and batrachians found in the vicinity of Norway, Oxford co. Maine. Bost. soc. nat. hist. Proc. ix : 195-99.

'69. [Note on occurrence in Connecticut and Massach usetts of A A c is . trod on contortrix ] -Bost. soc. niat. hist. Proc. xii : 249.

Wallace, W. S. 1901. Snakes of Rockland co., N. Y. Trans. Linn. soc. N. Y.

Placed at my disposal, in manuscript form, by the author, and as yet unpublished.

\section{CLASSLFICATION AND NOMENCLATURE}

The paper here presented is designed for general use, and is issued as a guide to our local species of serpents, with a view to obtaining farther data concerning the occurrence, frequency and variations of these species in different parts of the area under consideration. In order to popularize the subject as far as possible, certain changes from the usual form of presentation have been adopted.

In giving the specific descriptions, synonymic lists have been omitted, and the scientific names under which each species is described by De Kay ('42) and Jordan ('99) respectively have been added. In addition to an artificial generic key of the common type, based on structural characters of more or less moment, a highly artificial key to the species, based so far as possible on tint and pattern of coloration, has been devised; which will be of service in determinations of living specimens.

Prof. Cope's grouping and terminology, as fully developed in his last work (Cope. 1900) on North American serpents, have been strictly adhered to. This close following of what will undoubtedly be for many years the standard general work on the subject, seemed desirable in a paper such as the present, purely preliminary in its nature, though the author's views on several of the forms treated are widely at variance with those advanced by Prof. Cope.

To the scientific name of each species, has been added that one of its common names which seems to be in most general use, or 
which designates most correctly some character. In the few cases: where such names did not exist, descriptive names have been coined.

\section{Anatomic characters}

Serpents, or snakes, are reptiles with highly elongate, cylindric bodies, covered with scales, this covering being shed entire at certain seasons of the year. External limbs are either, as in our species, entirely wanting, or very rudimentary. The mouth is capable of great distension, most of the bones of the head being nnited by ligaments or muscles only, and possessing therefore great freedom of motion. External ears are lacking; as are eyelids, the eye being protected by an immovable layer of transnarent epidermis, which is shed with the skin. The tongue is forked, capable of protrusion, and retractible into a sheath. Teeth are always present, on both palatine bones and jaws. The digestive and respiratory organs are, like the general form, much elongated. The paired organs (lungs, etc.) are rarely bilaterally symmetric, one of the pair being usually rudimentary or wanting. The stomach is a simple enlargement of the digestive canal.

The snakes form a very compact and well marked group, easily separable by external characters from the nearest related forms. Among the lizards, it is true, certain serpentiform species occur, but not within the region covered by this paper.

But little definite information is at hand concerning the breeding habits of our snakes, even of the more common species. It is known that certain species are oviparous (laying eggs) while others. are ovoviviparous (the egg being developed and the young hatched before exclusion from the body of the mother). From the scanty data obtainable it seems probable that the New York species belonging to the genera $\mathrm{Colub}$ er, $\mathrm{Z}$ am en is, C y c lo p h is, Lio peltis, Osceola and Ophibolus are alloviparous; while in those of S toreria, Natrix, Eutaenia, Ancistrodon, Sistrurus and $\mathrm{Crotalus}$ the young are brought forth alive, owing to an early breaking of the eggshell. The manner of birth of the species of Diadophis, Carphophiops and Pityophis is unknown; and it seems possible that in Heterodon platy$r$ hin us both forms of birth may occur. 


\section{Venomous and nonvenomous snakes}

Of the species occurring within the area here discnssed; only three are venomous. These are the banded, or northern rattlesnake (p. 387); the massasauga, or prairie rattlesnake (p. 386); and the copperhead (p. 385). The three venomous species are closely related, all belonging to the family of Crotalidae, or pit-vipers, marked by the presence of erectile poison fangs on the upper jaw and by the presence of a deep pit between the eye and the nostril. The head is more or less markedly triangular in outline, and separated from the body by a relatively constricted neck. The rattles of the two species of rattlesnakes are of course an unmistakable characteristic. The copperhead bears no such distinguishing mark, and is frequently confused with the harmless hog-nosed snake, or blowing adder (p. 368), the water snake (p. 377) and occasionally even with the familiar milk snake (p. 374). A careful reading of the descriptions and inspection of the cuts given of these species, and comparison with those of the copperhead will make the points of difference clear.

Much attention has naturally been paid to the Crotalidae by American anthors, and numerons papers on the subject have been published. By far" the most valuable and comprehensive work on the venomous snakes of North America is that by Dr Lieonhard Stejneger ('95), curator of reptiles and batrachians at the United States national museum, to which the reader is referred for a very detailed diseussion of our poisonous snakes.
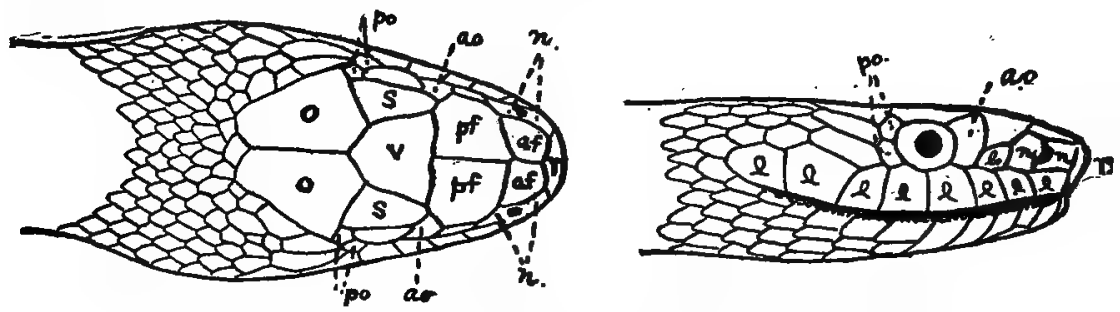

Fig. 1 Illustrating nomenclature of the head scales of serpents

Nomenclature of the scales

Certain terms frequently used in describing the characters of the species require definition here.

The vertical or frontal plate $(v)$ is the central, shield-shaped plate 
in the middle of the head above; on either side of it are the superciliary plates $(s)$ lying immediately above the eye. The pair of plates immediately in front of the vertical are the prefrontals $(p f)$; in front of these lie the internasals ( $a f)$, while the plate terminating the muzzle, and lying in front of the prefrontals, is the rostral $(r)$. The plates behind the superciliaries and vertical are the occipitals.(o). The plates immediately behind the eye are the postoculars, or postorbitals ( $p o$ ) ; those in front of the eye are the preoculars, anteoculars or anteorbitals (ao), in front of which are the loreals (lo). Between the loreal and the rostral, and inclosing the nostril, are the nasal plates $(n)$. The superior labials $(l)$ margin the upper jaw ; the inferior labials (not marked in figure) margin the lower jaw. The temporal plates lie between the superior labials and the occipitals.

The plates on the under side of the body, from the neck to the vent, are the abdominal plates, or gastrosteges; those from the vent to the end of the tail are the subcaudal plates, or urosteges. The anal plate is that immediately anterior to the vent. It may be entire, or divided by a longitudinal parting; and this difference is of value in the determination of the various snakes, as will be seen by reference to the artiticial key to the genera (p. 364). The term, "scales in . . . rows," will often be found in the specific descriptions, the number of rows referred to in such case being the number of longitudinal rows of scales, excluding the abdominal series. Keeled or carinate scales show a ridge on the median line.

\section{Variation}

Of late years much attention has been paid by naturalists to the subject of variation in animals, and certain relations between color variations and geographic distribution seem to be well established.

Certain species of suakes show variations in color and color pattern to a remarkable degree, notable examples of this being the common garter snake and the familiar, though somewhat scarcer, milk snake. Prof. E. D. Cope paid particular attention to the variations in these species, and has discussed the subject in a long series of papers several of which are cited in the accompanying reference list (p. 357). As noted earlier in this bulletin (p. 359) the grouping adopted in the present paper follows the views which he advanced 
in lis last discussion (Cope. 1900) of the forms mentioned. It would seem, however, that of the species occurring within the area here considered Eutaenia sirtalis and Osceola doliata and, to a somewhat less degree, $\mathrm{Natrix} f a s c i a t a$, require careful revision. With the seanty material at hand this is not possible at present for even the New York forms of those species, but a few very general notes will be found anong the specific descriptions.

Melanism, more or less complete, has been noted briefly under the two of our species which seem to be most subject to it. In Heterodon platyrhinus (p. 368) the black coloration has undoubtedly no systematic importance. In regard to $\mathrm{Natrix}$ f a s ciata siped on (p. 377), however, the case is somewhat different, as it would seem probable that in New York and New England specimens the darker coloration is general and not merely individual in its nature.

\section{DISTRIBUTION}

But little is known concerning the distribution throughout the state of the species here described. This lack of knowledge is particularly unfortunate because the reptiles, owing to their relatively low degree of mobility and restricted individual range would certainly seem to offer a much better basis for the definition of the faunal zones of any area than the birds or mammals. Local faunal lists giving details regarding the occurrence and abundance of the various species in different localities are therefore much to be desired. Such information on this subject as is now at hand has been appended to the specific descriptions. These brief notes are based on published papers by Dr Edgar A. Mearns ('98, '99), R. L. Ditmars ('96) and the author (1901); and on a manuscript list (1901) of the species found near Ithaca N. Y., which has been very kindly placed at my disposal by $\mathrm{H}$. D. Reed, of Cornell university. A paper on the snakes of Rockland co. N. Y. (soon to be published in the transactions of the Linnaean society of New York) has also been placed in my hands in manuscript by its author, W. Seward Wallace, for use in the present bulletin. It will be noted that nearly all our information, therefore, relates to the eastern and more particularly the southeastern portion of the state. With the exception of $\mathrm{Mr}$ Reed's notes, I have only scattered data on occurrences in the central and northern portions of the state, 
while not a single record lias been obtained from the southern tier of connties adjacent to the Pennsylvania border. In view of the number of educational institutions and local scientific societies in New York state, it seems curious that so little attention has been paid to this question. Data on the subject will be very acceptable to the anthor, who will also be glad to identify specimens sent to the state museum. Directions for collecting will be found in another section of this bulletin (p. 407).

\section{Key to genera}

The following artificial key to the families and genera of the species of snakes occurring in the area discussed is based on structural characters, often of slight systematic value, and follows closely the lines of the generic key in Jordan ('99).

\section{COLEBRIDAE}

A. No pit between eye and nostril; upper jaw with small teeth; neck not constricted; head more or less elongate; top of head covered with plates; form, in general, slender

a Dorsal scales carinated

1) Anal plate entire

a) Scales in 19-21 rows................ Euta enia (p. 381)

b) Scales in $27-31$ rows.............. Pit $\mathrm{y}$ op $\mathrm{h}$ is (p. 373).

2) Anal plate bifid

a) Scales in $15-17$ rows

* Tail one third or more of total length. Oy c lo p his (p. 369).

** Tail less than one third of total length. S S o re ri a (p. 380).

b) Scales in 19-27 rows

* Rostral recurved; scales in 25 rows. . He te r od on (p. 368)

* Rostral not recurved; gastrosteges less than $170 \ldots \ldots \ldots \ldots \ldots \ldots \ldots \ldots \ldots . \ldots \ldots$ Natrix (p. 376).

*** Rostral not recurved; gastrosteges more than $170 \ldots \ldots \ldots \ldots \ldots \ldots \ldots$ Coluber (p. 371)

$b$ Dorsal scales smooth

1) Anal plate entire

a) Head flattened..................... Os c e ola (p. 374)

b) Head conical ................... O p bibol us (p. 375)

2) Anal plate bifid

a) Scales in 17 rows..................... Za me n is (p. 370).

b) Scales in 13 rows; head not distinct. . Carph op hio ps (p. 366).

c) Scales in 15 rows; superior labials $8 \ldots \ldots$ Di a d o $\mathrm{p} \mathrm{h} \mathrm{is} \mathrm{(p.} \mathrm{36 \% )}$

d) Scales in 15 rows; superior labials 7....... Li o pelt is (p. 369) 


\section{CROTALINAE}

B. Deep pit between eye and nostril; upper jaw with erectile poison fangs; form stout; head more or less triangular; neck constricted; subcaudals entire

$a$ Tail without rattle....................... Ancis trod on (p. 385),

$b$ Tail with small rattle; top of head covered with plates............................ Sistrurus (p. 386).

c Tail with larger rattle; top of head covered with small scales ............................... Crotalus (p. 387)

\section{Color key to species}

The author has prepared a purely artiticial liey, based almost entirely on color and pattern, which is here appended. As it does. not require handling of the specimen, it furnishes a convenient. means of identifying live specimens whose specific character is in doubt. The numbers at the right refer to the similarly numbered. specific descriptions which begin on p. 366 of this bulletin.

Owing to the great variation in color and pattern sometimes. -shown by individual specimens, identifications made by means of any key based purely on these characters must not be accepted as decisive, but should be.verified by reading over the characters given in the specific descriptions, under the head of that species to which the: key seems to point; and by careful comparison of the specimen. with the figure given for each species.

a Color of back uniform; no marked spots, blotches or stripes

Color green; scales smooth........................... 4

Scales rough. ...............................

Color black; no lighter markings........................ 6 .

Some scales white-edged ......... ............ 8

Conspicuous yellowish neck ring...............

Color reddish brown; below pink; head not distinct from body....... 1

Color chestnut brown; below pink; head distinct from body....... . 17

Below grayish....................... 16.

b Striped longitudinally; with or without additional spots

Striped black and brown; no spots........................ 14

Brown and yellow; no spots; abdomen unicolor; very slender.. 18

Olivaceous and yellow or brown; dark spots on back and sides in several rows.............................. 20

Greenish brown and brown; below reddish yellow, with dark spots.

c Spotted, bloteled or transversely banded above

1) No rattle; head tapering into neck and body, not triangular 
Color black, with narrow yellow cross lines; hend black, spotted

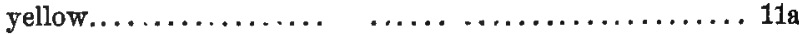

Brown to dark gray, with darker blotches; below clouded with reddish or yellowish $\ldots \ldots \ldots \ldots \ldots \ldots \ldots \ldots \ldots \ldots 12 a$

Reddish to purplish brown, darker blotches; below red, black

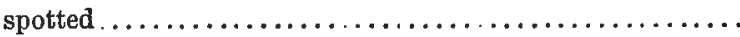

Light brown, with chocolate blotches; below yellowish white, black-blotched........................

Gray to brown, with dark blotches; below yellowish to greenish yellow; rostral recurved ...............

Ashy gray, with brown saddle spots; below tesselated with black. ................................. 10a

Whitish, with chestnut blotches, black margined; below yellowisb............................

Olivaceous to brownish, with black spots; below greenish white .............................. 20b

2) No rattle; head markedly triangular; neck constricted, distinct from body

Color brownish, with darker blotches; top of head copper red; below yellowish, with dark spots....................... 21

3) Tail terminating in a rattle; head very distinct, triaugular, neck constricted

Head covered with many small scales... . . . . . . . . . . 23

Head with a few large plates...................... 22

A. COLUBRIDAE

Top of head covered with plates; no pit between eye and nostril; upper jaw with normal (solid) teeth, no poison fangs; neck not markedly constricted; head more or less elongate; subcaudals divided. Species all harmless.

\section{Carphophiops amoenus (Say)}
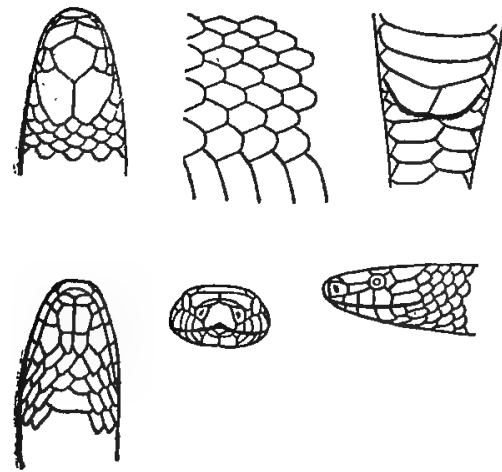

Fig. 2 Carphophiops amoenus

\section{Worm snake}

De Kay. Calamaria amoena Jordan. Carplophiops amoenus Head small, not distinctly marked off from body, frontal plate hexagonal, nearly as broad as long. Tail short, tapering to a point. Seales all smooth, in $\mathbf{1 3}$ rows.

Above bright chestnut brown, very glossy; beneath, bright salmon color. 
"Found under stones and logs." De Kay. "42

- "Rare around Nyack. I have seen but one specimen, taken in: 1899 at Blauveltville, Rockland co. N. Y." Wallace. 1901

Probably occurs quite commonly in all the northeastern states. Its small size, inconspicuous color, and habits render it difficult of detection, however. It is commonly found under stones or logs, or in fields during plowing.

\section{Diadophis punctatus (Linn.) Ring.necked snake}

De Kay. Coluber punctatus

Jordan. Diadophis punctatus

Head much depressed, flattened above; snout rounded; body slender ; tail tapering. Scales in 15 rows.

Bluish black above, with a yellow or yellowish white ring about neck; yellowish beneath, sometimes with spots. Length 18 inclies.

"Found in every part of the state. Common under

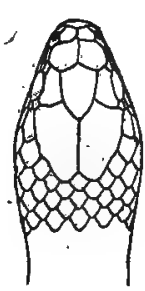
rocks and stones, and frequently seen under the bark of decayed trees." De Kay, ' 42 , p. 40

"Quite numerous." Mearns. '98, p. 326

"Rare (near Ithaca)." Reed. 1901

"Quite frequent in Rockland county. I captured a single specimen at Coldspring Harbor, Long Island, in August, 1899." Wallace. 1901

This snake may be common in southeastern New York, but it is rarely seen. I have secured but a single specimen in that region, taken in June 1901 near Fishkill village, Dutchess co. N. Y. 


\section{Heterodon platyrhinus Latreille}

\section{Blowing adder}

De Kay. Heterodon platy rhinos

Jordan. Heterodon platyrhinos

Body short and stout, tail very short and rapidly tapering. Scales markedly carinated. Rostral compressed and recurved. Scales in 25 rows.
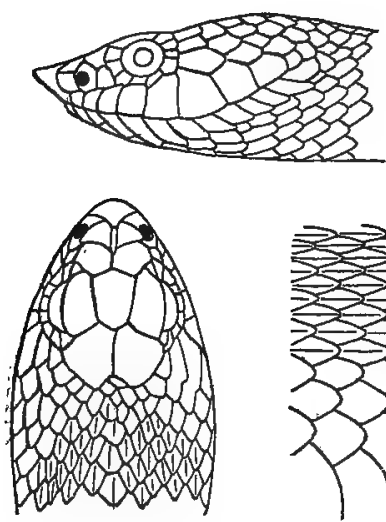
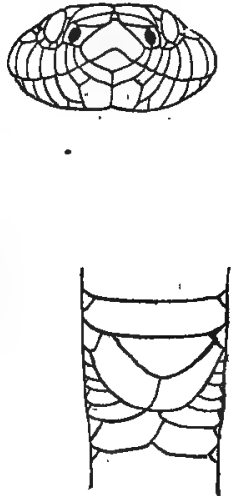

Color yellowish gray to brown, with dark brownish to black blotches on back, becoming black, half rings on upper side of tail; beneath, yellowish to greenish yellow. Length 30 inches.

Melanistic individFig. 4 Heterodon platyrhinus uals of this species seem to be quite common. They are recorded by Cope from Scarboro, Westchester co.; and have been taken by R. L. Ditmars in Sullivan county.

"Rather common in the southern parts of New York." De Kay. ' 42

"One of our common snakes" in the Highlands. Mearns. '98, p. 327

"Very common in sandy regions in Orange county and southern Westchester county." Eckel. 1901, p. 152

"Not at all common in Rockland county." Wallace. 1901

This species, thongh entirely harmless, is commonly regarded as venomous. When annoyed it flattens the anterior portion of its body, and hisses vigorously. Comparison of the above specitic description and figures with those of the copperhead (p. 385) will show the numerous puints of difference. 


\section{Liopeltis vernalis (De Kay)}

Smooth green snake

De Kay. Coluber vernalis

Jordan. Liopeltis vernalis

Head distinct; body slender. Scales smooth, in 15 rows. Tail less than one third of total length.
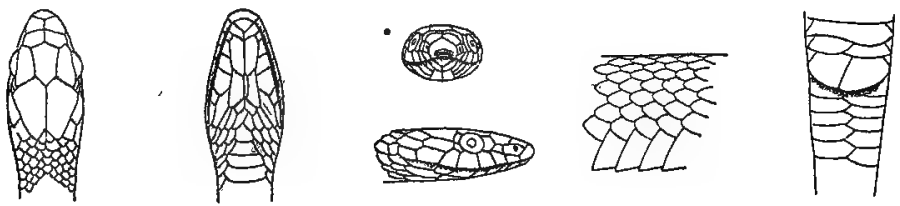

Fig. 5 Liopeltis vernalis

Above, green; yellowish to yellowish green beneath. Length 20 inches.

A somewhat smaller species than $\mathrm{Cycloph}$ is aestivus from which it is distinguished by its scales being smooth and in 15 rows, as well as by having a ploportionately shorter tail.

Common in many parts of the state. De Kay' 42 , states that it is "ver"y common in the marshes about Salina and Cayuga."

"Specimens taken on Staten Island, N. Y." Ditmars. '96, p. 14

"Still common in the Highlands." Mearns. '98, p. 326

"More common, I believe, in Orange county than east of the Hudson." Eokel. 1901, p. 152

"A number of specimens taken at Ithaca." Reed. 1901

"Quite common in Rockland county." Wallace. 1901

Specimens were taken by Baird near Westport, Essex co., and several have been sent to the state museum recently from Ausable Forks, Essex co. The species has been recorded as far north' as Nova Scotia. (Mackay. '96.)

\section{Cyclophis aestivus (Linn.)}

Rough green snake

De Kay. Leptophis aestivus

Jordan. Opheodrys aestivus

Head distinct; body slender. Scales strongly carinated, in 17 rows. Tail more than one third length of body.

Bright green above; light yellow below. Length 30 inches.

Distinguished from Li o peltis vernalis, our only other snake 
resembling it in color, by having keeled scales in 17 rows; while L. vern a lis has smooth scales, in 15 rows.

Commonly described as not occurring north of central New Jersey, but Ditmars ('96, p. 15) found it "quite common" in Plymouth counity, Ct.

$\mathrm{Mr}$ W. Seward Wallace, in his paper on the snakes of Rockland county N. Y., mentions its occurrence in that area; and in a recent
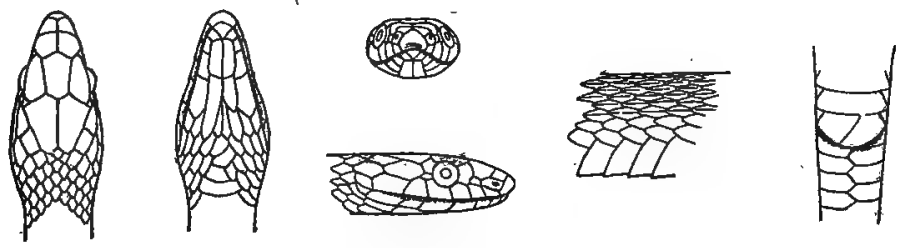

Fig. 6. Cyclophis aestivus

letter to me states that he does " not believe it to be rare, though it is not often seen, owing to its small size and secretive habits." In view of these records it is probable that the species will be found to occur in all the other southeastern counties, or at least in Westchester county and on Iong Island.

\section{Zamenis constrictor (Linn.) Black snake}

De Kay. Coluber constrictor

Jordan. Bascanion constrictor

Head distinct; body elongate. Scales smooth, in 17 rows. Color, in adult: lustrous pitch-black above; beneath, greenish black to
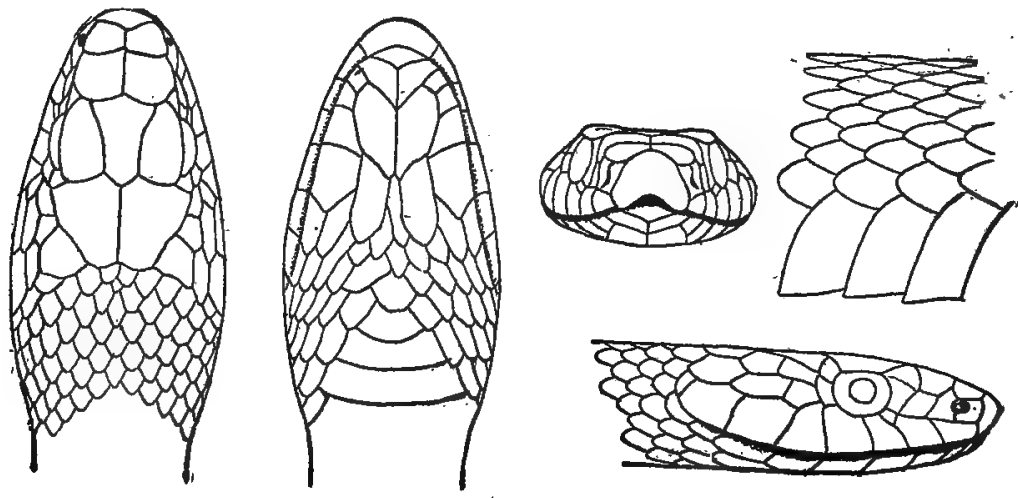

Fig. 7 Zamenis constrictor 
yellow. Young, olive, with darker dorsal blotches. .Length 50-60 inches.

"Formerly extremely abundant, now fairly so. A specimen taken May 25, 1883, measured 58 inches in length.' Mearns. '98, p. 326

"A very common species, both relatively and absolutely, in soutleastern New York." Eckel. 1901, p. 152

The department records show no evidence of a black snake having: been taken in the vicinity of Ithaca since 1883. In all my collecting about here, for the past three years, I have never seen or heard of one. If any have been taken recently, the fact has not come to our notice. Reed. 1901

"Very common in Rockland county, attaining a large size." Wallace. 1901

\section{Coluber vulpinus (B. \& G.)}

Fox snake

Jordan. Callopeltis vulpinus

Rostral broad; vertical plate broader than long. Scales in 27 rows (or occasionally 25); the níne dorsal rows carinated.
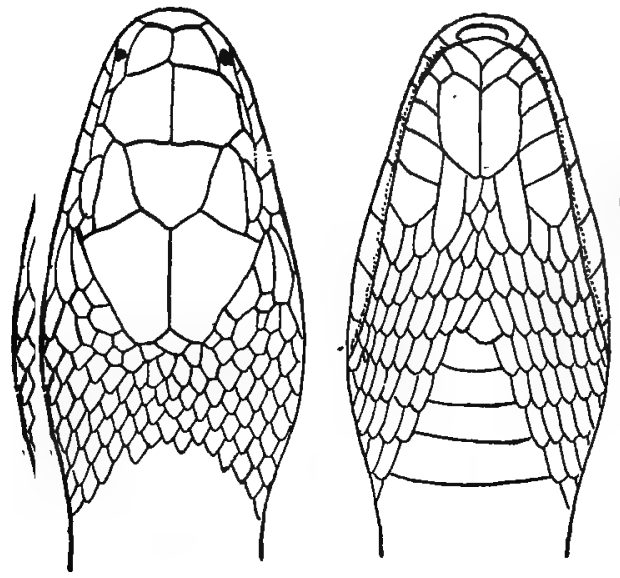

Fig. 8 Coluber vulpinus

Gronnd color above light brown, with a series of broad, transverse, quadrate, chocolate blotches; below yellowish white, with a series of subquadrate, black blotches on edge of abdomen, opposite to those of the dorsal series. Length 60 inches.

Included here because of one specimen, described by J. A. Allen. 
('69, p. 181) as captured in 1861 at Wenham Mass. No other specimen has ever been found within the area here discussed, and Cope (1900) states that it does not occur east of Illinois. Morse (1901), however, notes specimens from Ohio.

\section{Coluber obsoletus obsoletus Racer}

De Kay. Coluber alleghaniensis Jordan. Callopeltis obsoletus

Scales in 27 rows, the 17 dorsal rows keeled.

Color above, black or dark brown, with or without darker quadrangular blotches; occasional scales with white markings; greenish
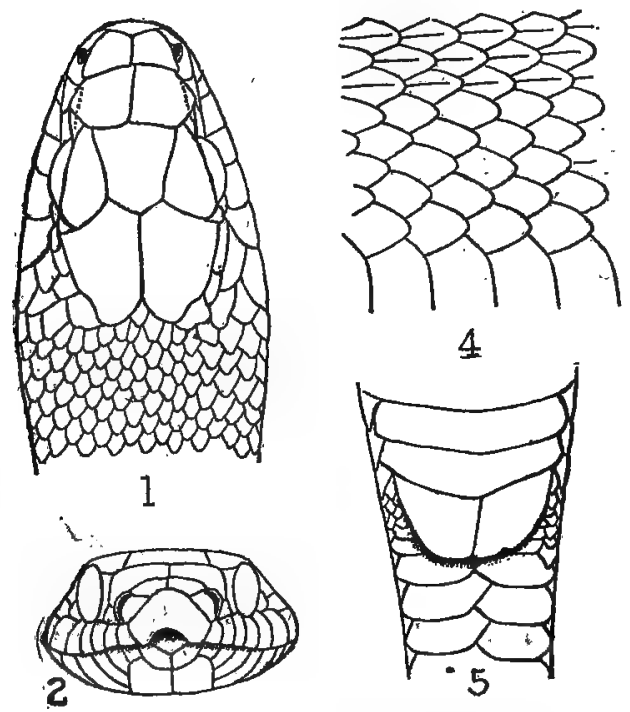

4
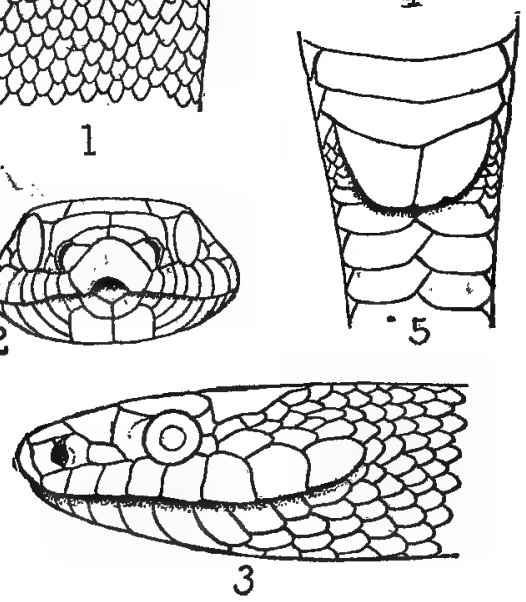

Fig. 9 Coluber obsoletus obsoletus white to slate color below. Length 50-75 inches.

Found in the Highlands. De Kay, p. 37

"Formerly quite common; now rare." Mearns. '98, p. 327

"Occurs in Orange county (and probably east of the Hudson), though much scarcer than $\mathrm{Za}$ menis constrictor. Eckel. 1901. p. 152

"Specimens captured near Ithaca, June 4, 1883, and summer of 1889 ; at Chittenango, by D. G. Gates, Ap. 27, 1889. A specimen $150 \mathrm{~cm}$ long captured alive at Newfield was sent to Cornell university in August 1899."

Reed. 1901

"Occurs in Rocklánd county." Wallace. 1901 


\section{Pityophis melanoleucus (Daudin) Pine snake}

De Kay. Pituophis melanoleucus

Jordan. Pituophis melanoleucus

Head short, elevated; rostral plate-compressed and narrowed above. Scales in 27 to 31 rows, all save the outer four rows on each side being keeled.
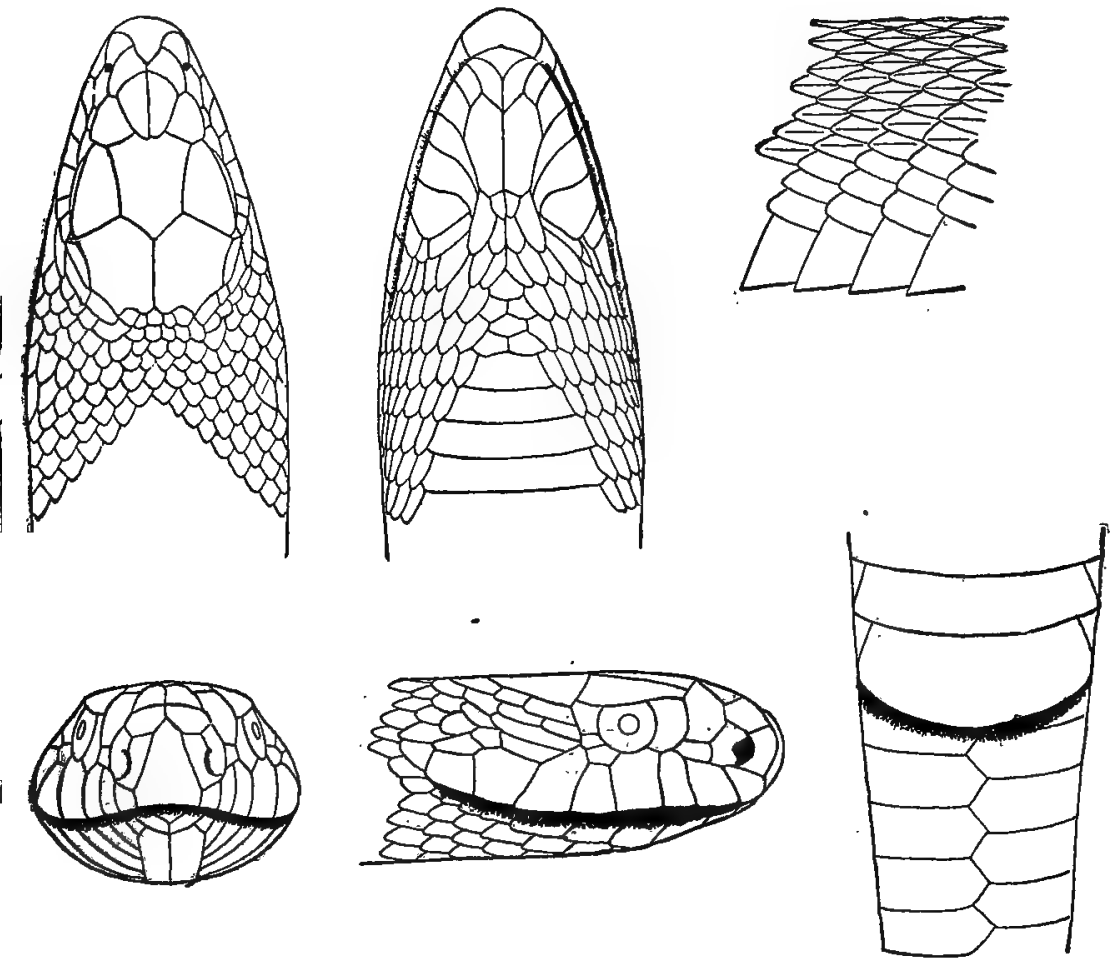

Fig. 10 Pityophis melanoleucus

Head spotted with black; color above whitish, with a series of chestnut brown blotches, margined with black; abdomen yellowish. Length 60 inches.

"I have seen but one of these snakes in Rockland county (on Tallman's mountain, near Nyack, at an elevation of about 500 feet A.T.), but it is said to be quite common in the county." Wallace. 1901

Mr Wallace's record is of great interest inasmuch as it verifies, 
after the lapse of almost sixty years, De Kay's prediction that the species "will probably be found in this state." The pine snake may reasonably be expected to occur in Orange county also, but I have no record of it from that area.

\section{Osceola doliata (Linn.)}

\section{Jordan. Lampropeltis doliatus}

Scales in 21 rows: head flattish. Ground color above varyingfrom ashen to bright yellow, but only appearing as transverse interspaces between the brown to reddish spots or saddles which cross the back. Length $30-50$ inches.

Osceola doliata is one of our most variable species. The subject exn not well be discussed in the present builetin, and the reader is referred to Prof. Cope's papers, the more important of which are cited in the accompanying reference list, for a full presentation of his views. The subspecies next described - the familiar milk suake-is the only form of Osceola doliata. occurring in New York. Several specimens in the state museum, however, taken near Albany $N$. Y: agree much more closely with Cope's O.d.clerica than with O.d.triangula. As Albany is well on toward the northern limit of Osceola doliata the significance of this variation in its bearing on Cope's views of the geographic distribution of the various "subspecies" is apparent. Specimens of the "milk snake" from any part of the state would on this account be particularly acceptable to the author.

\section{0a Osceola doliata triangula (Boie)}

\section{Milk snake}

De Kay. Coluber eximius

Jordan. Lampropeltis doliatus triangulus

Above yellowish gray, with a dorsal series of large brown to chocolate blotches, bordered with black. On each side, on the second to fifth rows of scales, is another series of similarly colored but smaller spots, alternating with the dorsal series. Still another series of blotches, entirely black, occur on the edges of the gastrosteges and the three lowest scale rows. On the head the ground color is exposed as a patch, triangular in outline, the apex being directed backward. Below yellowish white, tesselated with black. 
"Generally distributed near New York city, but not common." Ditmars. '96, p. 13

"A very uncommon species." (in the Highlands.) Mearns. '98; p. 327

"A rather common snake in Orange county; less abundant, I believe, east of the Hudson." Eckel. 1901, p. 152
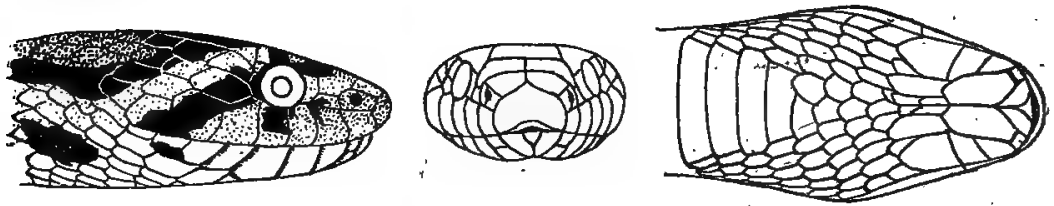

Fig. 11 Osceola doliata triangula

"Apparently not common in the immediate vicinity of Ithaca. Farther away from the town they appear to be more common." Reed. 1901

"Common in the villages and farming country of Rockland county." Wallace. 1901

\section{Ophibolus getulus (Linn.)}

Jordan. Lampropeltis getulus

Head little distinct, conic, not depressed, the muzzle slightly compressed and the rostral plate projecting beyond the lower jaw. Tail short. Scales smooth, in 21 to 25 rows.

Ground color black, marked above and below with yellow or - white spots or bands. Top of head black, with white or yellow spots.

Several subspecies exist, the only form occurring within our limits, however, being that next described-Ophibolus getulus getulus.

\section{1a Ophibolus getulus getulus (Linn.) \\ Chain snake}

De Kay. Coluber getulus

Jordan. Lampropeltis getulus

Scales smooth, in 21-2e rows.

Head black, with yellow spots; color above black, crossed by about 30 narrow, continuous yellow lines, which bifureate on the flanks; below, yellow, blotched with black. Length 50 inches.

"Not uncommon in the pine woods of New Jersey, and also found, but rarely, in what are called the brush plains of Long Island." De Kay. ' '42, p. 38 
Hough, ('52, p. 23) in describing his collection made for the state museum in St Lawrence county, notes that this species is "of common occurrence in this section of the state." The specimens then sent in have disappeared, so that the record can not be verified; but, as I have stated, (1901) Gebhard, then curator, was competent to make the specific determination and would hardly have allowed an obvious error to be published. The species can not well be confused with any other New York form, and Hough's record can not
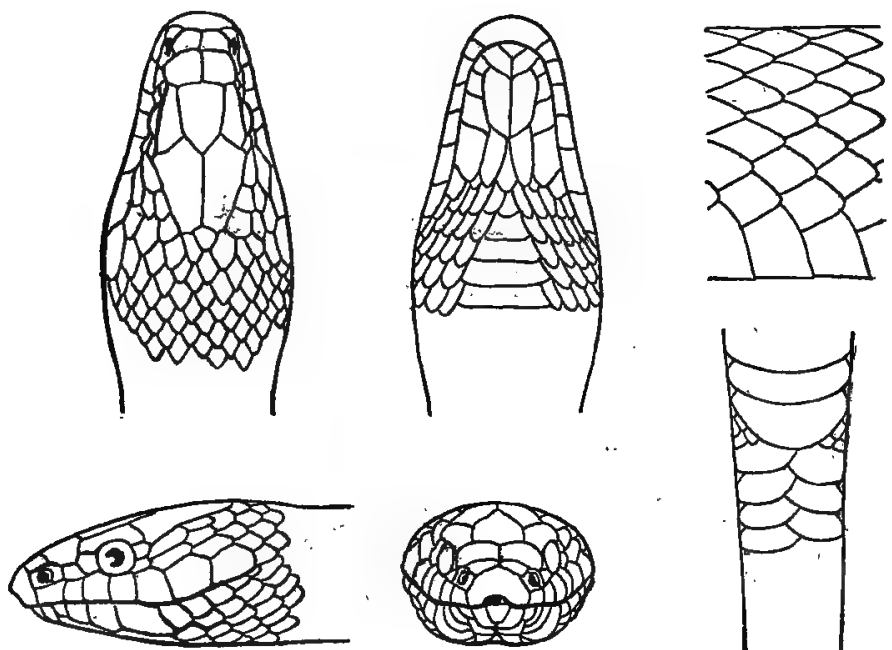

Fig. 12 Ophibolus getulus getulus

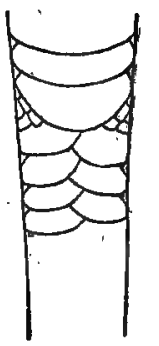

be neglected or suppressed; but, if true, the distribution thus given the chain snake is remarkable. Further data on this point would be of great service, and I would consider it a favor if some St Lawrence county naturalist would investigate the matter.

\section{Natrix fasciata (Linn.)}

Jordan. Natrix sipedon

Scales all carinated, in 23 or 25 rows. General form robust; tail not long. General color above bright reddish brown to gray, nsually marked by large, dark brown, transverse spots; below yellowish or reddish, usually with more or less rounded spots of chestnut or reddish brown. Length 30-50 inches.

Of the "snbspecies" listed by Cope, only one (N.f. siped on) is definitely known to occur within our limits. Both W. H. Smith 
('82) and Morse (1901), however, have reported Natrix fas ciata erythrogaster from Ohio. The Jatter states that it is the most: eommon form in certain localities on Lake Erie. The value of the identitication is problematic, but as the localities are definitely given, and the specimens are now in the zoologic museum of Ohio state university, it would seem that the question could be conveniently and finally settled by submitting a suite to Dr Stejneger. The importance of these Ohio specimens in the present connection is that, if the subspecies is found as described by the authors noted, it may be expected to occur in wèstern New York. The subspecies is marked off from all others of the Natrix fasciata by being unspotted. both above and below, the coloration above being uniform reddish black, and below yellowish red.

\section{2a Natrix fasciata sipedon (Linn.) \\ Water snake}

De Kay. Tropidonotus sipedon

Jordan. Natrix sipedon

General color dull brown to dark gray, with darker transverse spots; below yellowish, with cloudy blotches of brownish or reddish. Length 30-50 inches. General form robust.
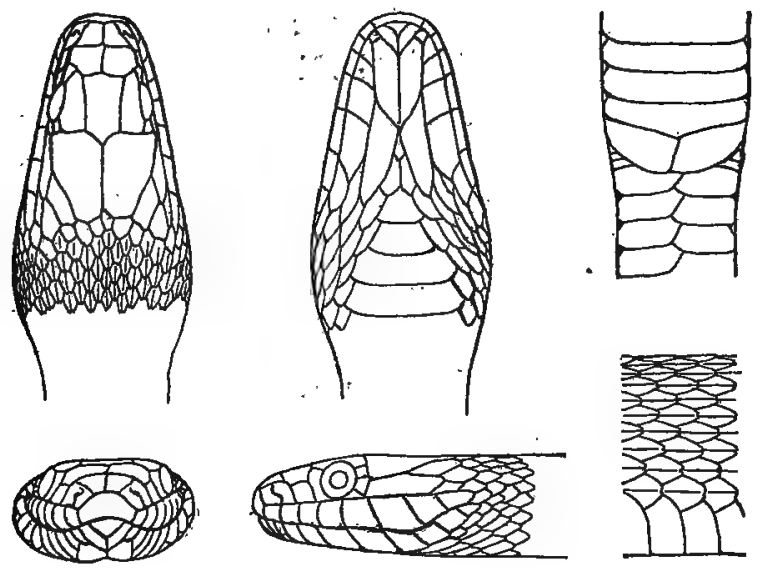

Fig. 13 Natrix fasciata sipedon

New York and New England specimens seem, in general, to be darker in coloration than those from more southerly areas. Holbrook's type of Tropid on otus niger came from New England 
where, he says, the "species" was common. The water snake appears to be common throughout the state in ponds and streams, though rarely found away from their immediate vicinity. It is a particularly bad tempered species, but its bite is, of course, perfectly harmless. In its coloration and general form it bears some resemblance to the poisonous "moccasin" (A ncistrodon piscivo$r u s)$ of the southern states, with which it is frequently confused. Its resemblance to the copperhead (Ancistrodon contortrix) (p. 385) is much less close.

"One of our largest, handsomest and most abundant snakes." Mearns. '98, p. 326

"Abundant in all the counties of southeastern New York." Eckel. 1901, p. 152

"Abundant near Ithaca; common at Hornellsville." Reed. 1901

"Often seen along the banks of the Hackensack and other streams in Rockland county, but not so common as the black snake." Walzace. 1901

\section{Natrix rigida (Say) Stiff sinake}

De Kay. Tropidonotus rigidus

Jordan. Regina rigida

Scales carinated, in 19 rows. Muzzle short. Upper surface of
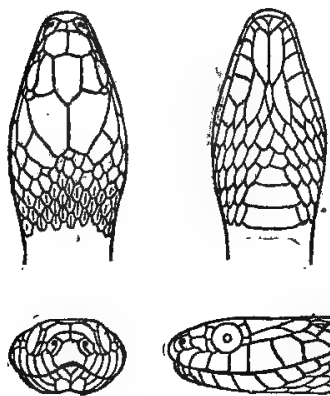

Fig. 14 Natrix rigida
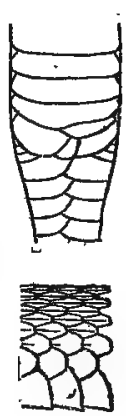
head flat. Above greenish brown, with two deep brown dorsal stripes; abdomen reddish yellow, with two series of deep brown to black spots. Length 24 inches.

Cope (1900, p. 959) mentions that this species ranges north to Pennsylvania.

\section{Natrix leberis (Linn.)}

\section{Leather snake}

De Kay. Tropidonotus leberis

Jordan. Regina leberis

Head small; little distinct from body; depressed and flattened. Scales carinated, in 19 rows. 
Above chestnut brown, with a lateral yellow band, and three narrow black dorsal stripes; abdomen yellowish, with four brown longitudinal bands.

Length 24 inches.

From description only, this species might possibly be confused with $\mathrm{Eu}$ taenia saurita, which is also

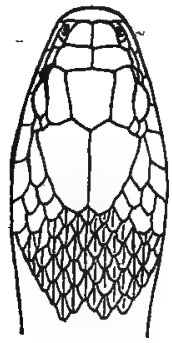
striped longitndin'ally, though with differently arranged colors: Both spe-
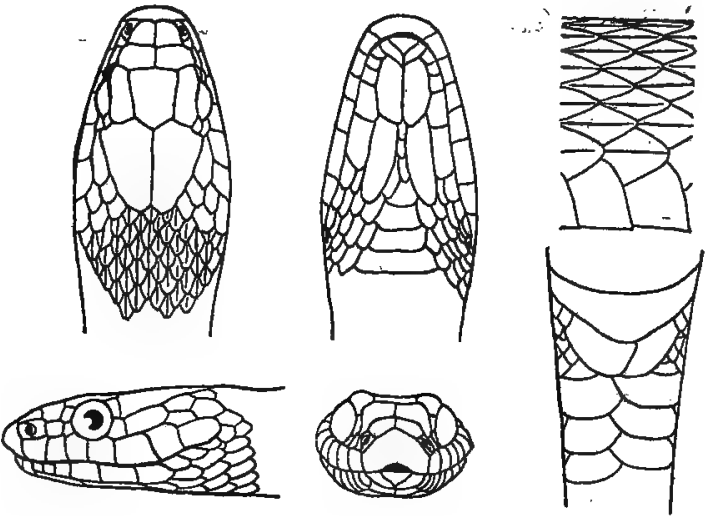
cies are highly aquatic in habit.

Fig. 15 Natrix leberis

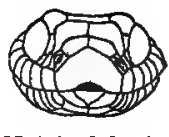

Natrix leberis, though included in many fannal lists, seems to be scarce throughout our region, as nearly every observer states that he has never met it, himself, but includes it on good authority.

Cope $(1900$, p. 995) notes a specimen (no. 10,729) in the U. S. national museum from Livingston county, N. Y.

\section{Natrix kirtlandii (Kennicott) \\ Kirtland's snake}

Jordan. Clonophis kirtlandi

Head very small; not distinct from body. Scales very strongly keeled, in 19 rows.

Above, light reddish to purplish brown, with four rows of large darker blotches on back and
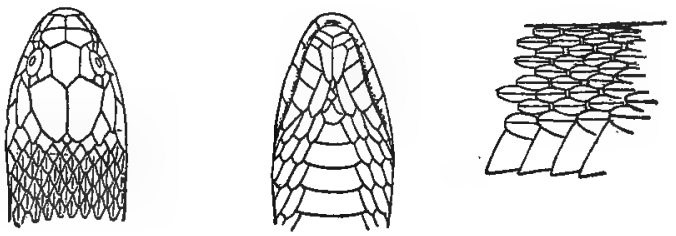
sides; beneath, pale brick red, with black spots. Length inches.

Recorded by Ab-
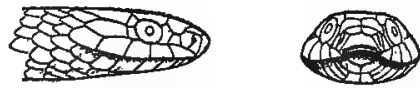

Fig. 16 Natrix kirtlandii

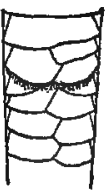
bott ('68) from New Jersey, but the identification apparently doubted by Nelson ('90). Cope (1900, p. 997) restricts its range to Wisconsin, Michigan, Illinois, Indiana and Ohio. 


\section{Storeria dekayi (Holbrook)}

De Kay's brown snakie

De Kay. Tropidonotus dekayi

Jordan. Storeria dekayi

Head distinct from body. Scales keeled, in 17 rows. One preocular.
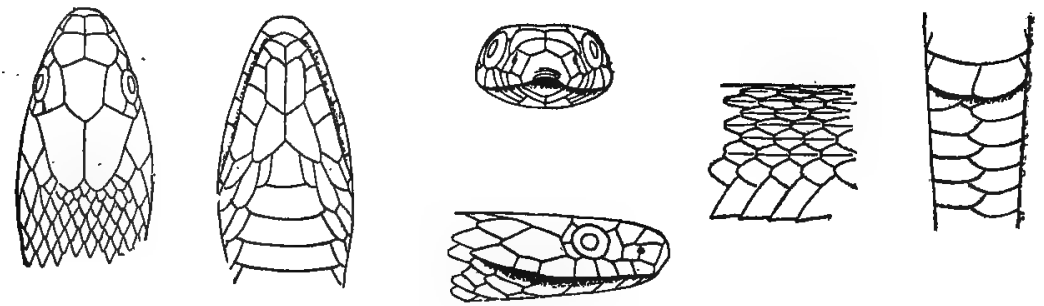

Fig. 17 Storeria dekayi

Color above, gravish brown to chestnut brown; with a rather faint dorsal band of lighter brown, margined by dark brown or black dots; below, grayish white. Length 12 inches.

Distinguished from Carphophiops amoenus and Storeria occipitomaculata by its gray (instead of reddish), coloration below; and farther from $\mathrm{C}$. a m o e $\mathrm{n} \mathfrak{u}$ s by the distinctness. of its head.

"Quite common in rocky portions of Central park." Ditmars. $\therefore 96$, p. 21

"Abundant in southeastern New York." Eckel. 1901, p. 153

"Occurring, but not common, in Rockland county." Wallace. 1901

\section{Storeria occipitomaculata (Storer)}

Brown snake

Jordan. Storeria occipitomaculata

Head distinct from body. Scales keeled, in 15 rows. Two anteoculars.
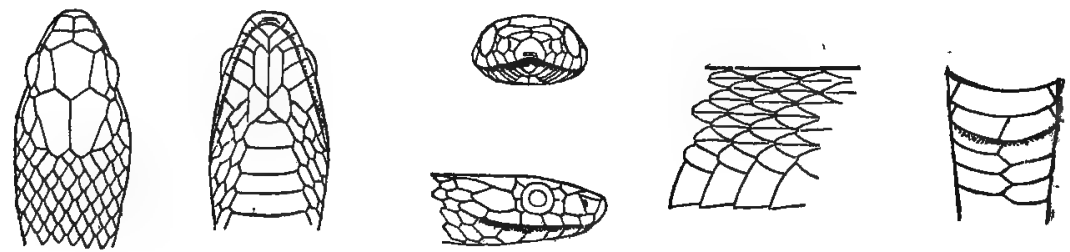

Flg. 18 Storerla occipitomaculata 
Above, grayish brown to chestnut brown, sometimes with a palerdorsal band; three light colored spots behind head; beneath, salmon. pink. Length 15 inches.

"Extralimital ; Massachusetts." De Kay, p. 41

"Common under stones and leaves." Mearns. '98, p. 327

"Common in the Schoharie ralley; most often seen after sundown." Mearns. '99, p. 345

"Abnndant in sontheastern New York." Eckel. 1901, p. 153

"Fairly common near Ithaca." Reed. 1901

"Common in the farming country, but seldom seen in the hills, of Rockland county." Wallace. 1901

\section{Eutaenia saurita (Linn.) \\ Ribbon snake}

De Kay. Leptophis saurita

Jordan. Thamnophis sauritus

Form elongate; slender; scales strongly keeled, in 19 rows; tail one third (or more) of total length of body.

Color light brown, with three light yellow stripes which are often margined with black; abdomen greenish white. Length 36 inches. The lateral stripe is
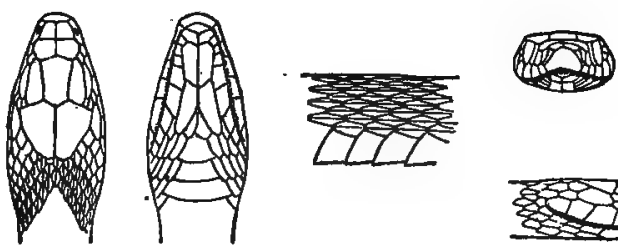

Fig. 19 Eutaenia saurita

on the third and fourth rows of scales, while in Eutaenia sirtalis it occupies the second and third rows.

"Common, especially in tields and meadows through which streams flow and where mice are abundant." Mearns. '98, p. 327

"In Westchester and Putnarn counties this species appears to beeven more abundant than Eutaenia sirtalis." Eckel. 1901, p. 154

"Common near Ithaca." Reed. 1901

"Frequently found in Rockland county." Wallace. 1901 


\section{Eutaenia brachystoma (Cope)}

Head not distinct from neck; superior labials six; inferior labials eight. Scales keeled, in 19 rows. T.wo distinct nasal plates. Tail one fourth total length.

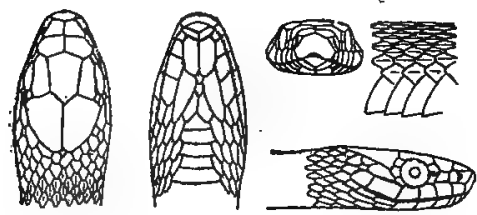

Fig. 20 Eutaenia brachystoma

Color below, líght olive, unspotted; above darker olive, with a broad, brown band on each side, extending from the fourth to the middle of the ninth row of scales, inclusive; chin yellowish.

The type specimen, and the only one so far obtained, is stated by Cope (1900, p. 1057) to have come from Franklin, Venango co. Pa.

\section{Eutaenia sirtalis (Linn.)}

Garter snake

De Kay. Tropidonotus taenia

Jordan. Thamnophis sirtalis

Head distinct, oval; body moderately robust; form in general much stouter than Eutaenia s a rita; tail between one quarter and one fifth of total length. Superior labials eight; inferior labials 10 ; scales keeled, in 19 rows. Color above varying from jight green through olivaceous to black, usually traversed by three longitudinal stripes, of which the laterals are not well defined, and all three may be very faint or entirely wanting. Below, usually light bluish green, but varying to darker and even to black.

This, the common "garter snake," is abundant throughout the state, and ranges in altitude from tide level to the highest summits of the Catskills and Adirondacks. It is the most variable of American serpents, no less than six "subspecies" having been recorded from the area here considered. In the author's opinion, howerer, these six forms are of very unequal systematic value, and calling all of them subspecies merely results in rendering that term meaningless. At some fiture time the author hopes to be in a pusition to discuss the New York forms, at least, in more detail; but at present this is inpossible, owing to lack of the large series of fresh specimens which such an investigation would require. This being the case, the six "subspecies" noted have been listed and described on the following pages, but the reader may expect to find 
specimens of Eutaenia sirtalis agreeing with several of the: subspecific descriptions, or differing from all of them.

\section{0a Eutaenia sirtalis graminea (Cope)}

Green garter snake

Above, light green, with no stripes or spots on upper side of body or head; below yellow, clouded with green. Lips, chin and throat uniform yellow.

Cope (1900, p. 1067) lists specimens from Ohio, Massachusetts. and Maine. I have never seen a New York specimen of E u ta en ia. sirtalis approaching the coloration of this form.

\section{0 b Eutaenia sirtalis ordinata (Linn.) \\ Spotted garter snake \\ Jordan. Thamnophis sirtalis ordinatus}

General color greenish brown or olive; stripes faint; three series: of small square dark blotches on each side; beneath, greenish white, with spots of black near each end of the gastrosteges; upper labial. plates all edged prominently with black.

I have found this "subspecies":at Vernon, Oneida co., Peekskill, Westchester co., Central Valley, Orange co. A specimen is in the museum collection, taken by Dr M. S. Farr at Kenwood, Albany co., and another, less typical, taken by Dr Tarleton Bean at Patchogne, Long Island. Ditmars ('96, p. 20) mentions specimens taken on Long Island, and at Fort Lee N. J.; while Wallace (1901) notes the occurrence of the subspecies in Rockland county.

\section{0c Eutaenia sirtalis sirtalis (Linn.)}

Striped garter snake

Color above the yellowish lateral stripes dark olive to dark brown; a narrow, rather indistinct greenish yellow vertebral line; three
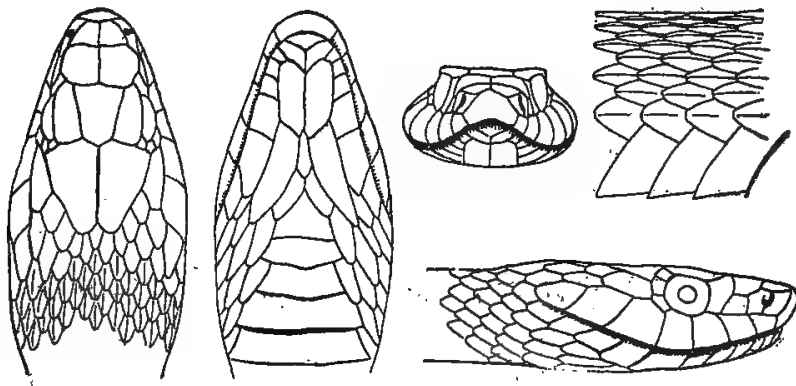

Fig. 21 Eutaenia sirtalis sirtalis 
series of small indistinct spots on each side; below, greenish white; black blotches on gastrosteges near outer margins.

Common everywhere throughout the state, though possibly many ispecimens identified as belonging to this subspecies may have been really one of the three following.

\section{$20 \mathrm{~d}$ Eutaenia sirtalis obscura (Cope) \\ Dusky garter snake}

Jordan. Thamnophis sirtalis obscurus

A yellowish dorsal band, with lateral bands less distinct; ground color, exposed between these bands, is uniformly brownish, caused by the complete fusion of the spots shown on other subspecies; below, grayish green, with black spots near ends of gastrosteges.

Specimens noted by Cope (1900) from Westport, Essex co.

20e Eutaenia sirtalis dorsalis B. \& G.

Red garter snake

Jordan. Thamnophis sirtalis dorsalis

Ground color brownish; lateral stripes olivaceous; dorsal stripe bright red; lateral spots separated by red interspaces.

From descriptions given in many of the faunal lists published for the region under consideration, I am led to believe that many specimens from New England and northern New York are to be classed with the "dorsalis" group, and I have therefore inserted a description of its týpical subspecies.

\section{$20 f$ Eutaenia sirtalis pallidula (Allen)}

General color above, olive to olive brown; dorsal stripe, except at its inception, almost obsolete; the interlinear spots of reddish scales with narrow black edgings and black interspaces. Belly, in young specimens grayish white, in adnlts from grayish white to light yellowish.

The above description is quoted from Allen ('99) where the subspecies is first described, a paper to which readers are referred for a more detailed description. In this paper Mr Allen gives its distribution as "from the White mountains of New Hampshire and the Adirondacks of New Tork, northward into New Brunswick and Nova Scotia, and possibly farther;" while in a later communication to the anthor he instances a specimen of this subspecies caught at Chateangay, Franklin co. N. Y. 
The anthor has not seen the specimens on which this subspecies is based, but from the published description the form seems to be entitled to as much recognition as E. s. graminea, and certain other forms to which Cope has given subspecitic rank.

\section{B. Crotalidae}

Deep pit between eye and nostril; head rather markedly triangular; neck constricted; subcaudals entire. No normal (solid) teeth upon the upper jaw, which carries erectile lollow poison fangs. All the species are venomons.

\section{Ancistrodon contortrix (Linn.) Copperhead}

De Kay. Trigonocephalus contortrix Jordan. Agkistrodon contortix

No rattle. Top of head with nine symmetric plates in front; scales behind. Scales in 23 rows. General form robust.
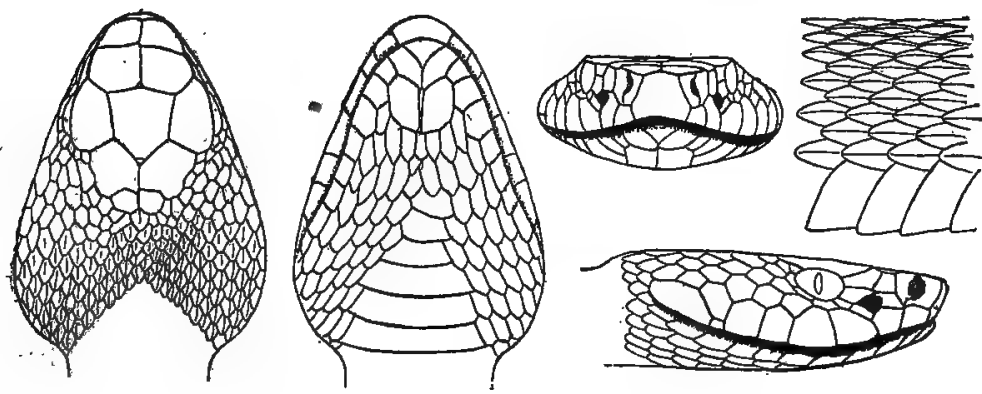

Fig. 22 Ancistrodon contortrix

Above hazel brown, becoming bright copper colored on head; darker chestnnt colored blotches on sides; beneath dull yellowish, with a series of distinct, large, dark blotches on each side. Chin and throat unspotted. Sides of head crearn color. Length 40 inclues.

"Though found in the western part of the state, most numerous in the meadows of Columbia and Dutchess counties." De Kay,'42

Ditmars ('96, p. 23) mentions occurrences at Alpine N. J., and in Putnam, Westchester and Dutchess counties, $\mathrm{N}$. Y.

" Much more common than the 'rattler.' Some are killed in hayfields in the neighborhood of Highland Falls, Orange co. each year." Mearns. '98, p. 327 
"Occurs in swamps and low grounds in Orange and Dutchess counties, but scarcer in the Highlands." Eckel. 1901, p. 154

"Very common in Rockland county." Wallace. 1901

The milk snake (p. 374); the water snake (p. 377) and the blowing adder (p. 368) are frequently confounded with this species, though bearing only a very superficial resemblance to it.

\section{Sistrurus catenatus catenatus (Rafinesque)}

\section{Massasauga}

Gebhard. '53, p. 22. Crotalophorus tergeminus

Jordan. S istrurus caten atus

Tail with a rattle. Head with nine symmetric plates in front; covered with scales behind. Scales in 25 rows. Urosteges undivided, except the last three to five, which are bifid.
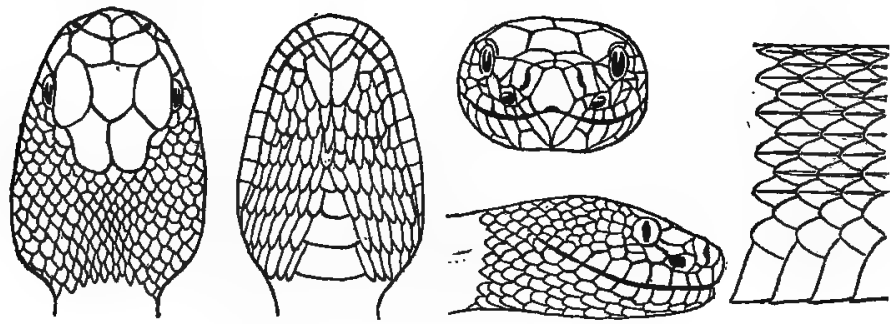

Fig. 23 Sistrurus catenatus catenatus

Ground color above, brown; blotches deep brown to blackish, with yellowish white margin; color beneath, blackish brown, intermingled with yellowish. Length 24-30 inclies.

The rattles of this species are much smaller than those of a banded rattlesnake of equal length; and their sound is correspondingly feeble.

Described by De Kay ('42, p. 57) as extralimital, this species was added to the New York faunal list by Gebhard ('53, p. 22), a specimen having been sent in by the Hon. Levi Fish, from the town of Byron, Genesee co. Gebhard states further that in this town "their habitat is a white cedar swamp, containing an area of about one thousand acres. During the summer season, they leave the swainp, and go into the adjoining fields of grain, where they remain until fall, when they return to the swamp and hibernate." No later record exists of their occurrence in Now York state; and 
the species has never been noted from any of the other states falling within the scope of this paper. It occurs, however, in Ohio (W. H. Smith, '82, p. 672), from which state it is also listed by Cope (1900, p. 1149) and Morse (1901).

It seems highly probable that many of the western New York localities given by Macauley ('29) for the rattlesnake may, in reality, refer to this species.

\section{Crotalus horridus Linr.}

\section{Banded rattlesnake}

De Kay. Crotalus durissus

Jordan. Crotalus horridus

Tail with a rattle. Top of head covered entirely with scales. Scales in 29 rows.

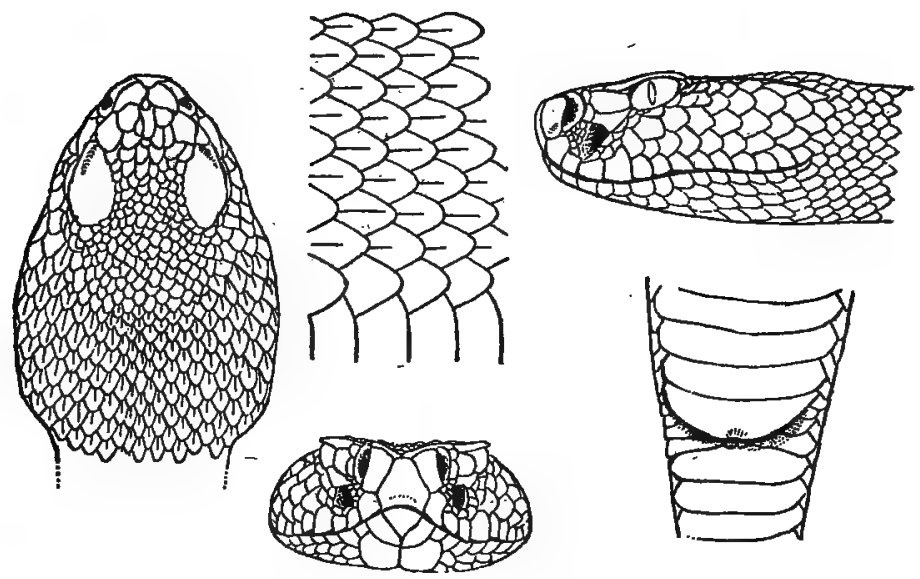

Fig. 24 Crotalus horridus

Color above, bright yellowish to dark brown; two series of dark brown to black spots on each side of median line, often confluent açross back; tail black; below, yellowish white to gray. Length 60 inches.

Macauley ('29, p. 514) gives an interesting and detailed account of the distribution, at that date, of the rattlesnake.

"They are found on Long Island and Manhattan Island; in some parts of the Highlands; around the head of Lake Champlain ; at and around Lake George; at Glenville, in the county of Schenectady; at the Noses, in the county of Montgomery; along some parts 
of Unadilla and Susquehanna rivers; at Lenox and Sullivan, in the county of Madison; at Manlins and Onondaga, in Onondaga county; in some parts of the county of Ontario; along Genesee and Niagara rivers; and in many places in the Oak lands, between those rivers, and also east of the former'; at several places along the Schoharie creek; at the Helderberg, in the county of Albany; at Snake hill, near Newburg ; and in some other places."

De Kay ('42), says of the species :

"It is common in various parts of the state, and in the northern states generally appears to prefer rocky situations. They abound in Clinton, Essex and Warren counties, along the shores of Lakes Champlain and George. Although numerous in the rocky mountainous districts of this state, they are rare or entirely wanting in those elevated regions which give rise to the Moose, the Racquette and the Hudson rivers. They are found in the counties of Sullivan, Ulster, Orange and Greene. A few still linger in the swamps of Suffolk county."

"Becoming quite rare within 50 miles of New York city, the nearest locality in which it has been found in the past few years being Putnam county, N. Y.; it also occurs in Connecticut, and Prof. E. B. Southwick tells me that a few are found annually in the central part of Long Island." Ditmars. '96, p. 24

"Forinerly numerous about Highland Falls; now extremely rare." Mearns. '98, p. 327

"Still occurs in Orange and Rockland counties, but rery rare and possibly extinct east of the Hudson in this state. Cope notes a specimen collected in 1878 at Katonah, Westchester co.; and I have been informed that one was killed in 1897 near White Plains N. Y." Eckel. 1901, p. 155

"Still met with in Rockland county." Wallace. 1901

Rattlesnakes are occasionally reported from the western counties of this state. It is possible that some of these accounts may refer to the massasanga ( $\mathrm{p}$. 386) whose present distribution in the state is unknown. 


\section{LIZARDS, TORTOISES AND BATRACHIANS OF NEW YORK}

BY F. C. PAULMIER PH. D.

\section{INTRODUCTION}

The following catalogue describes the lizards, tortoises and batrachians which occur in New 1 ork or which from their occurrence in adjoining states may be expected to be found here. Since the appearance of Holbrook's and DeKay's work, no papers dealing with these forms as a whole, have appeared, except those of Sherwood and Smith which catalogue the species found near New York city. Thus practically nothing is known of the forms found in the northern and western part of the state and collections made there would be of great value in studying the distribution of the groups.

The main works on the lizards, tortoises and batrachians are included in the following bibliography. Other references will be found in the list on p. 357, where such works are marked with an asterisk. The descriptions are taken mainly from the papers by Cope and Jordan.

Cope, E. D. '89. The batrachia of North America, U. S. nat. mus. Bul. 34. 1889.

'98. Crocodilians, lizards and snakes of North America. U. S. nat. mus. Rep't. 1898.

Jordan, D. S. '99. A manual of the vertebrate animals of the northern United States. Ed. 8. 1899.

DeKay, J. E. '42. Natural history of New York. Zoalogy of New York. v. 3. Reptiles and amphibia. 3, text; 4, plates. 1812.

Holbrook, J. E. '42. North American herpetology. 1842.

sherwood, W. I. '94. Salamanders found in the vicinity of New York city, with notes on extralimital or allied species. Linn. soc. of N. Y. Abst. proc. 1894-95. No. 7.

- 97. Frogs and toads found in the vicinity of New York city. Ibid. 1897-98. No. 10.

Smith, Eugene. '98. Turtles and lizards of the vicinity of New York city. Ibid. 1898-99. No. 11. 


\section{A. LACERTILIA \\ Lizards}

Long-tailed reptiles, covered with scales; nsually with four limbs: terminating in claws. The young undergo no metamorphosis, being: hatched from the egg in a form resembling the parent. Lizards prefer warm climates and but three species are found within one limits, two being fairly common, while the other is recorded only once from this state.

\section{Sceloporus undulatus Latreille}

Common lizard, swift, fence lizard, pine lizard

De Kay'. Tropidolepis undulatus, the brown swift, p. 31, pl. 8, fig. 16

Brownish olive or gray, with black, wavy, $V$ shaped bands on each side; throat and sides of belly in male, blue with a black edging. Length 7 inches.

Its eggs, which are long and narrow, are laid in the sand about June 1 and hatched about July 10.

Found in southern part of the state. Very rapid in its movements, and frequently found under bark of decayed trees. It chooses old fences as its basking places.

\section{Eumeces quinquelineatus Linn.}

\section{Blue-tailed lizard}

De Kay. Scincus fasciatus, blue-tailed lizard, "scorpion," p. 29, pl. 8, fig. 17

Color variable, but usually olive with five yellowish streaks, the middle one forking on the head; tail bright blue. Old specimens. become reddish and stripes grow fainter and may disappear. Length 8-11 inches.

Found in the southern part of the state; lives on the ground; is very active; it readily parts with a portion of its tail when an attempt is made to capture it.

\section{Liolepisma laterale Say \\ Ground lizard}

Upper parts of head and body reddish olive; on each side a black: stripe; the sides below this lateral band striped alternately dusky

${ }^{1}$ Ref'erences to De Kay under the different species refer to the Zoology of Neno Fork, Reptiles and amphibia, v. 3, text; v. 4, plates, by James E. De Kay, 1842. 
and lighter; abdomen yellowish; tail pale bluish or greenish below. Length 5 inches.

Usually considered a southern form; but Cope notes a specimen taken in Burlington county, N. J.; and H. D. Reed informs me that a specimen in the collection of Cornell university was captured Ap. 23, 1892, on the Caroline hills, southeast of Utica N. Y. by W. J. Terry.

\section{B. CHELONIA}

\section{Turitles}

The turtles and tortoises, which comprise the order Chelonia, may be defined as reptiles having the skeleton mainly external. The body is inclosed in a shell of bony plates consisting of a dorsal carapace (to which the vertebrae and ribs are firmly fused) and a ventral plate or plastron. Both of these are covered over with horny plates which are composed of the well known tortoise shell. ${ }^{1}$

The vertebrae of the neck and tail are free and movable. The limbs are well developed and usually terminated by claws. In some forms there is a web between the toes, while in the marine forms (not included in this list) the feet have the form of flippers. Teeth are never developed, the jaws being covered by a layer of horn.

Their eggs, which have a tough leathery shell, are laid in the dry sand and are hatched by the heat of the sun. Like all reptiles, the young leave the egg in the form of the parent, and thus do not undergo any metamorphosis, as do the batrachians. They breathe by lungs throughout their entire existence.

The Chelonia are found both on land and in water, many forms being apparently equally at home in either.

Onaiting the marine turtles, our forms represent four families.

1 Trionychidae, soft-shelled turtles

2 Chelydridae, snapping turtles

3 Kinosternidae, box or musk turtles

4 Emydidae, pond turtles

\section{Family 1 TRIONYCHIDAE Soft-shelled turtles}

Body flat, round; carapace not completely ossified, and with the

1 The tortoise shell of commerce is derived from one of the marine forms. 
plastron covered by a thick leathery skin, flexible at the margins; neck long and flexible, snout pointed and tubular; feet webbed. Aquatic, carnivorous and very voracions.

\section{Amyda mutica Le Sueur}

\section{Leather turtle}

A depression along median line of carapace, no spines or tubercles; olive to brown, young spotted; feet not mottled below. Length 12 inches.

Probably found in the northern part of the state in Lakes Erie and Ontario and the streams flowing into them.

\section{Aspidonectes spinifer Le Suenr Soft-shelled turtle}

De Kay. Triony $x$ ferox, p. 6, pl. 6, fig. 11

Carapace slate-colored with spots; legs and feet mottled everywhere with dark ; anterior part of carapace with tnbercules.

Found in Lakes Ontario and Erie, from which they come through the Erie canal to the Hudson; also in sonthwestern part of state.

\section{Family 2 CHELYDRIDAE \\ Snapping turtles}

Represented by one species with the characters of the family.

\section{Chelydra serpentina L.}

Snapping turtle

De Kay. Chelonura serpentina, p. 8, pl. 3, fig. 6

Yonng dusky brown with dark spots; head very large; jaws strong; tail long and strong, with crest of compressed tubercles; plastron small, cross-shaped, leaving the body largely uncovered; toes partially webbed. Length 24 inches.

Found all over the state in quiet waters. Its snapping propensities are well known. In the spring it lays 60 to 70 eggs in the sand, frequently at some distance from the water (De.Kay).

\section{Family 3 Kinosternidae}

Box turtles

Carapace long and narrow, lightest behind; margins turned downward and inward rather than outward; plastron large; head pointed; limbs slender. 


\section{Kinosternun pennsylvanicum Bose}

\section{Mud tortoise}

De Kay. K. pennsylvanicum, p. 21, pl, 2, fig. 4

Shell dusky brown; head dark, with light dots. Differs from the following species in that the plastron is divided into two parts, so that the animal can shut itself up almost completely. Length 4 inches.

Rare but may be taken in southern part of the state. Frequently found on land.

\section{Aramochelys odorata Latreille Musk turtle, stink pot}

De Kay. Sternothaeius odoratus, p. 22, pl. 7, fig. 13

Shell dnsky, sometimes spotted, usually covered with mud and green algae; neck with two yellow stripes; plastron cross-shaped, somewliat like $\mathrm{Ch}$ ely dra but larger; head large, jaws strong, odor strong musky.

Found in ponds and ditches all over the state. Is a nuisance to fishermen, whose hooks it takes.

\section{Family 4 EMYDidae Pond turtles}

Carapace ovate, broadest behind, the margins having a tendency to flare outward; plastron covering entire ventral surface, its plates 12 in number.

\section{Graptemys geographicus Le Sueur Map turtle}

De Kay. Emys geographica, The geogrnphic tortoise, p. 18, pl. 4, fig. 7

Dark olive brown with network of greenish or yellow lines, more prominent on edges of carapace; head and neck also with yellow stripes; plastron yellowish; carapace notched behind and keeled.

Found in streams in western part of state.

\section{Graptemys pseudogeographicus Holbrook}

De Kay. Emys pseudogeographicus, the pseudogeographic tortoise, p. 19 , pl. 2, fig. 3

Mnch like preceding but browner, the markings on the shell pale and in larger pattern; keel of carapace stronger, back of each plate in the middle line projects over succeeding one; plastron yellowish, marbled with reddish brown; head and legs with bright yellow stripee. 
Said by De Kay to have been taken in Lake Erie. A western form.

\section{Malaclemmys centrata Labr. Salt marsh turtle, diamond back}

De Kay. Emys palustris, the salt water terrapin, p. 10, pl. 3, fig. 5

Greenish or dark olive, plates of both shells usually with concentric dark stripes, sometimes grooved. Length 10 inches.

Occasionally found along the coast; the only one of our turtles except the true marine forms, which is found in salt water.

\section{Pseudemys rubriventris Le Conte}

\section{Red-bellied terrapin, stider}

De Kay. Emys rubriventris, p. 16, pl. 7. fig. 14

Dusky or blackish with irregular red markings, specially on edge of shell ; plastron red and yellowish with dark spots; head and neck brown with reddish and yellowish lines.

In streams in the southeastern part of the state. Used as a substitute for the real terrapin.

\section{Pseudemys hieroglyphica Holbrook}

Shell depressed, olive brown, marked with groups of concentric yellowish lines; plastron yellowish; head very small with yellow lines.

A southwestern form, habitat given by Jordan aș New York to Wisconsin and south.

\section{Chrysemys picta Herm.}

\section{Painted turtle, mud turtle}

De Kay. Emys picta, p. 12, pl. 5, fig. 10

Greenish black, plates edged with yellow; the marginal plates marked with bright red; plastron yellow with brown blotches; legs and tail with red lines; upper jaw notched in front. Length 6 to 8 inches.

Very common throughout the state, preferring quiet waters and frequently seen basking in the sun, on logs.

\section{Chrysemys marginata Agassiz}

Colors similar to preceding, but plates of carapace alternating; the lateral rows out of line with the middle one, instead of forming three sets of three as in above; lateral plates with strong concentric grooves. Possibly a form of the preceding.

Found in the western part of the state. 


\section{Chelopus muhlenbergii Schw. Muhlenberg's tortoise}

De Kay. Emys muhlenbergi i, Muhlenberg's tortoise, p. 17, pl. 8, fig. 15 Brown with yellowish markings; plastron black with yellowish blotches; an orange spot on each side of the neck; plates of back plain or concentrically grooved. Length $4 \frac{1}{2}$ inches.

Southern part of state, particularly in the branches of the Delaware river.

\section{Chelopus insculptus Le Conte \\ Wood tortoise}

De Kay. Emys insculptus, wood terrapin, p. 14, pl. 4, fig. 8

Carapace with a keel, its plates marked with concentric striae and radiating black lines; ground color yellowish or reddish brown; plastron with a black blotch on each plate. Length 8 inches.

All over the state, taken both in land and water.

\section{Chelopus guttatus Schnei.}

Speckled tortoise

De Kay. Emys guttata, the spotted tortoise, p. 13, pl. 16, fig. 12

Black with yellow spots, whose number varies with age, the the young having only a single spot on each plate; plastron yellow, blotched with black. Length $4 \frac{1}{2}$ inches.

Common in ponds all over the state, frequently seen sitting on logs.

\section{Emydoidea blandingii Holbrook \\ Blanding's tortoise}

De Kay. Cistud o blandingi i, p. 25, pl. 1, fig. 2

Black with numerous round or oblong yellow spots; plastron with a transverse hinge, as in the common land tortoise, enabling the animal to shnt itself up tightly. Young jet jlack without spots.

Rare but possibly to be taken in this state.

In habits similar to following.

\section{Cistudo carolina $\mathrm{L}$. Box tortoise}

De Kay. C. carolina, box turtle, p. 24, pl. 21, fig. 1

Colors highly variable, usually yellowish brown with spots and blotches of yellow; plastron with a hinge, as in preceding. Length Ð-7 inches.

Found all over the state in dry places. 


\section{BATRACHIA}

Batrachians, or amphibians, are vertebrates with soft skins, which possess gills, either during their earlier or larval stages only or thronghout life, and which usually breathe by lungs in the adult.

The living representatives of the group are divided into three orders : 1) Proteida, which retain their gills throughout life, and of which our only representative is the mud puppy, Necturus; 2) Urodela, long-tailed forms which lose their gills in the adult stage and include the salamanders and newts $;^{1}$ and 3) (Anura) Salientia, tailless forms, without gills in the adult and with hind legs adapted. for leaping, and including the frogs and toads.

The adult batrachians are found mostly in moist places, their soft. skins generally unfitting them for the hot, dry places which many of the reptiles are so fond of. Thus the greater number of forms are found in or near water (frogs and some salamanders) or under stones and logs in woods (most salamanders). A few, such as the tree frogs are arboreal; others, inclnding some of the salamanders and the wood frog, are found on the ground in dry woods; wlile the common toad is found everywhere on land.

In the spring, however, almost all forms seek the water to breed. Their eggs are the round black bodies contained in the transparent jellylike masses which are so frequently found in ponds. These give rise to the well known limbless tadpoles, or polliwogs, which. possess gills and are thus fitted for a subaquatic, fishlike existence. After a shorter or longer period, the limbs appear and lungs develop, while the gills disappear (in most cases), so that the animal becomes an air-breathing, instead of water-breathing form.

The batrachians are all perfectly harmless forms and, with very few exceptions, never even attempt self-defense. For their protection from enemies they rely on their coloration and on their places of concealment.

Their food consists alnost entirely of insects, so that they have a distinct economic value.

1 There is no common Americun term for these forms, though the word lizard is occasionally cmployed. This is a misnomer, as the lizards are reptiles, which, while they resemble the hatrachions in form, have a scaly skin and never have: gills. 
Plate 1.

1
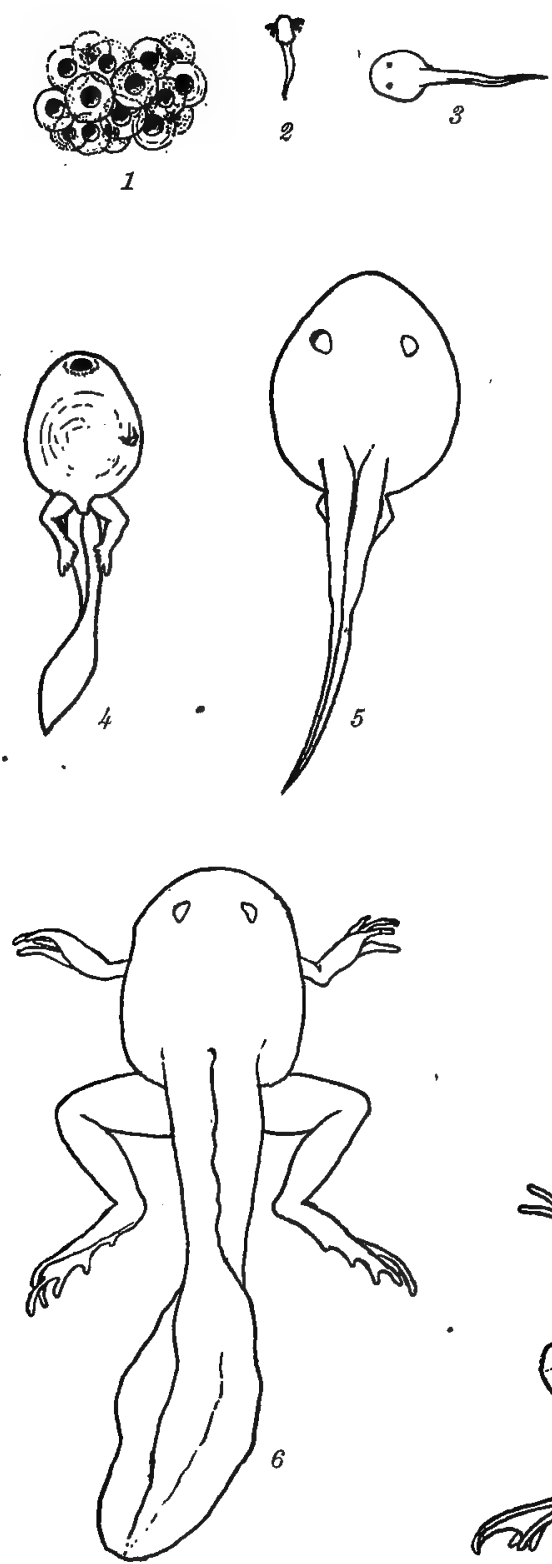
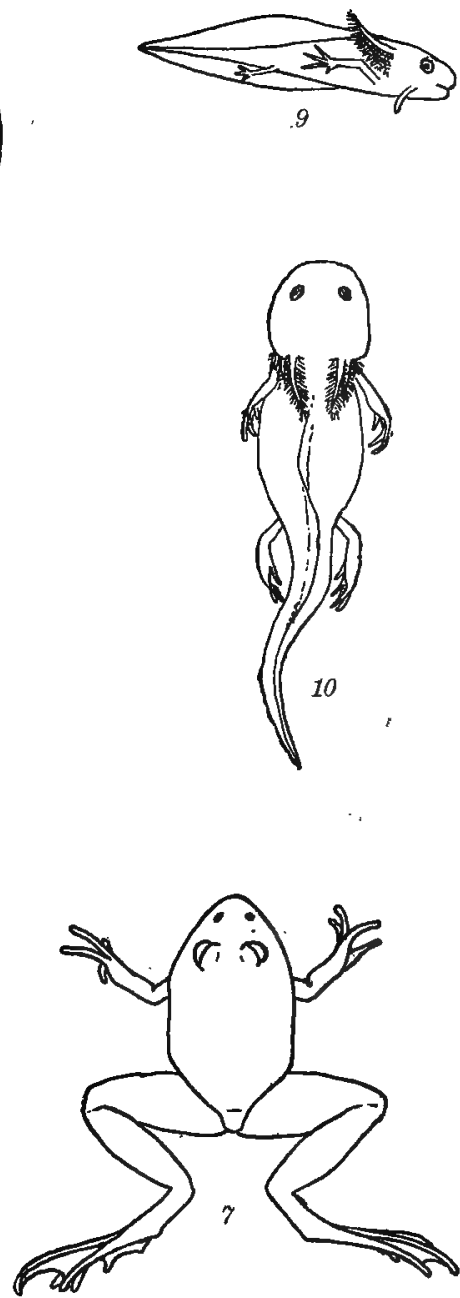

Metamorphoses of Batrachia

Fig. 1-7 Development of frog

Fig. 8-10 Stages in development of salamander 



\section{Order 1 PROTEÏDA.}

Large eellike forms, which retain their external gills throughout life. Lungs are developed, but are not normally functional. Only one family.

\section{Family Proteidae}

Represented here by one species.

\section{Necturus maculatus Rafinesque Mud puppy}

De Kay. Me nobranchus lateral is, The banded proteus, p. 8\%, pl. 18, fig. 45 .

Much the largest of our batrachians, except the hellbender, reaching a length of 2 feet. Eellike, with feeble legs; light chocolate brown, with darker brown spots. Three pairs of bushy, bright red, external gills.

Common in most of the larger streams and lakes of the northern and western part of the state. Found in the Erie canal. De Kay ('42) stated that it wonld soon be found in the Hudson river, a prediction since verified, as numerous specimens are now taken around Albany. Information as to how far up and down the river it has reached is greatly to be desired.

\section{Order 2 URODELA \\ Salamanders}

Include all the rest of the long-tailed batrachians. No gills in , . , the adult stage; limbs equally developed. The eggs are usually laid in the water either singly on leaves or in masses like those of the frog. Thre larvae or tadpoles differ from those of the frogs and toads in that the gills are not covered over, but remain external and do not disappear till a late stage. A pair of processes known as balancers occurs in front of the gills. Three stages in their development are shown in fig. 8-10 of pl: 1 .

The following families are represented within our limits.

1 Cryptobranchidae.

2 Amblystomidae

3 Plethodontidae

4 Desmognathidae

5 Pleurodelidae 


\section{Family 1 CRYPTOBRANCHIDAE Giant salamanders}

Represented by one species with the characters of the family.

2 Cryptobranchus allegheniensis Daudin

\section{- Hellbender}

De Kay. Menopoma alleghaniensis, the Alleghany hellbender, p. 89, pl. 18 , fig. 44

A large form, reaching at times, 2 feet. Generally lead-colored; occasionally spotted; head broad and flat; body with a lateral fold of skin. A very unprepossessing but harmless creature. Nothing is known of its breeding liabits.

Probably found in the branches of the Alleghany river in the western part of the state. Where it is common, it annoys fishermen by taking their hooks. It is remarkably tenasious of life.

\section{Family 2 AMBL ystomidaE Blunt-nosed salamanders}

Except for the two preceding forms the members of this family are the largest and stoutest of our salamanders. They are almost entirely land forms, except in the breeding season, the spring, when they migrate to the ponds to lay their eggs. These are somewhat larger and fewer than frogs eggs, and the jellylike mass surrounding them is whiter and more opaque.

\section{Amblystoma opacum Gravenhorst}

De Kay. Salamandra fasciata; the blotched salamander, p. 77 , pl. 17, fig. 40

Black above, with about 14 bluish gray bars running across; belly dark blue. 11 costal grooves between legs. Length $3 \frac{1}{2}$ inches; very stout.

Southern part of state. This species is found in dryer places than the majority of salamanders, even on bare rocks in the sun (Mearns) and in sandy places (Cope). 


\section{Amblystoma punctatum Linn. \\ Spotted alamander}

De Kay. Salamandra subviolacea, large spotted salamander, crimson spotted triton, p. 74, pl. 16, fig. 36

Black above, with a series of round yellow spots on each side of the back; body broad, depressed, and swollen; tail not as long as rest of body. 11 costal grooves on each side. Length $6 \frac{1}{2}$ inches.

Probably generally distributed over the state. Found under rocks and decaying trees, and occasionally wanders into cellars.

\section{Amblystoma conspersum Cope}

\section{Smaller spotted salamander}

Lead-colored, with one or two series of small yellowish spots along: sides; skin smooth; body more slender than the preceding; tail shorter than head and body. 11 costal grooves. Length about 4 inches.

Taken in Pennsylvania, and may be found in southern part of this state.

\section{Amblystoma tigrinum Green}

De Kay. Triton tigrin us, tiger salamander, or triton, p. 83, pl. 15, fig. 32

Dark brown, with usually, many irregular yellow blotches' sometimes arranged in cross bands; body thick and strong; head long; tail about equal in length to body. 12 costal grooves. . Length 8-10 inches. The largest of our salamanders and very variable.

All over the state. Said by De Kay to be found in decayed, hollow trees, but usually in burrows and under stones.

\section{Amblystoma jeffersonianum Green}

De Kay. Sala mand ra granulata, the granulated salamander, p. 78, pl. 23, fig. 66; Triton niger, the dusky triton, p. 85, pl. 15, fig. 35

Olive-brown or blackish, usually with bluish spots, but sometimes uniformly lead-colored; head small; eyes far back; body slender. 12 costal furrows. Length $5-8$ inches.

Two varieties, possibly throughout the state. According toDe Kay, inhabiting wet, springy places.

The three following families of Urodela, while possessing well marked osteologic differences, show no external characters sufficiently obvions to distinguish them easily. For this reason no description has been attempted. 


\section{Family 3 PLETHODONTIDAE}

\section{Hemidactylium scutatum Schlegel}

\section{Four-toed salamander}

Brown above; snout yellow; whitish below with dots like ink :spots ; skin tinely granulated, resembling scales. Somewhat resembles Plethod on cinereus, but has only four toes on each foot. 14 costal furrows. Length $2 \frac{1}{2}$ inches.

Probably to be found in this state.

"Under logs and rails in open woods at some distance from water." W. H. Smith. '82

\section{Plethodon cinereus Green}

De Kay. Salamandra erythronota, the red-backed salamander, ${ }^{p}$. 75 , pl. 16 , fig. 38

Three subspecies of this form are distinguished by Cope.

a Plethodon cinereus cinereus, color, liver-brown, below dirty white mottled with black, giving a "pepper and salt" appearance, sometimes yellowish toward the head. 18 costal grooves.

$b$ P. c. erythronotus. Form and structure similar to above but back with a broad, reddish stripe. 18 costal groores. Resembles Spelerpes bilineatus, but in that form the belly is unspotted and there are fewer costal furrows.

c P. c. dorsalis. Quite similar to c. erythronotus but with only 16 costal furrows. Much rarer than the others.

All these subspecies are entirely terrestrial and found under stones and logs in woods. Eggs laid in a little package under stones in damp places. The young possess gills when hatched, but very soon lose them. The most abundant salamander, found everywhere, specially in the mountrins.

\section{Plethodon glutinosus Green}

Dc Kay. Salamandraglutinosa, the blue-spotted salamander, p. 81, pl. 17 ; fig. 42

Skin covered with a milky secretion. Black, usually with bluish white blotches and specks; head, body and tail continnous and rounded. Much like Amblystoma jeffersonianum, bnt has lighter spots and shorter digits. 14 costal furrows. Length $5-7$ inches. 
Entirely terrestrial and found in the mountains, where it prefers the coolest spots. Both in rocky localities and in forest mold and fallen logs.

\section{Gyrinophilus porphyriticus Green}

De Kay. Salamandra salmonea, salmon-colored salamander, p. 75, pl. 16, fig. $: 9$

Yellow or purplish brown or salmon-colored, irregularly blouched with gray; white below, tail rounded at base. 16 costal furrows. Length 6 inches.

An aquatic mountain form, preferring cool mountain springs and swamps to streams.

"This is the only one of our eastern salamanders that attempts defense. It snaps tiercely but harmlessly and throws its body into contortions." Cope

\section{Spelerpes bilineatus Green}

De Kay. Salamandra bilineata, the striped back salamander, p. 77 , pl. 23 , fig. 67

Yellow; back with a tinge of brown which is bordered by a darker brown line; belly yellow, unspotted; tail slender and compressed, longer than rest of animal. 14 costal grooves between the limbs. Length 3 inches.

Occurs all over the state; in shallow, stony brooks, but occasionally found under stones or bark. Very active and behaves like Desmognathus fusca, with which it is frequently found.

\section{Spelerpes longicauda Green Cave salamander}

De Kay. Sa la mandra $\operatorname{long}$ i cauda, long-tailed salamander, p. 78, pl. 17, fig. 41

Bright lemon yellow, back and sides covered with black specks running into bands on the tail ; belly unspotted; tail one and one half times as long as body and very compressed. 12 costal grooves. Length 5 inches.

Found in rocky ground and in fissures and caves. Said by De Kay ('42) and W. H. Smith ('82) to be aquatic. Probably rare.

\section{Spelerpes ruber Daudin}

De Kay. Sa l am andra ru bra, red salamander, p. 80, pl. 17, fig. 48 Orange red, with numerous crowded dark spots; between these is a clouding of dark red brown; under sur fave with very small black 
dots. Almost as stout as A m blyst om a punctatum, but no neck; head passing into body, which is of the same diameter throughout and passes insensibly into the square tail, which narrows toward tip. 15 costal furrows. Length 6 inches.

Generally aquatic, preferring cold springs, and is found on the ground only after rains. Occasionally found under bark of fallen trees in very damp places.

\section{Family 4 DESMOGNATHIDAE}

\section{Desmognathus ochrophaea Baird}

Alleghany mountain salamander

Brownish yellow with brown shade on each side; a yellowish dorsal band with few spots; belly unspotted. 13 costal furrows. Length 3 inches. Very like Spelerpes bilineatus, but has a more rounded tail, a paler abdomen, and a light bar from eye to. mouth. Its habitat is also quite different.

Found in the Adirondacks and Catskills, under bark and decaying trees; not aquatic.

\section{Desmognathus fusca Rafinesque}

De Kay. Sal amandra picta, dusky salamander, p. 75

Very variable in color, but usually brown above with gray or purplish spots becoming blackish wich age; marbled below; eyes. prominent; tail as long as head and body. 15 costal grooves. Length 4-5 inches.

This species makes a curious disposition of its eggs, one of the sexes wrapping the albuminous egg string around the body and remaining concealed in a comparatively dry spot till the eggs hatch.

One of the commonest salamanders; found in rapid and shallow streams under stones.

\section{Desmognathus nigra Green}

Unifiorm black, with a very stont body, the stoutest in fact of our salamanders. 12 costal grooves. Length 6-7 inches.

Found in Pennsylvania and may be taken in southern part of state in the monntains. Habits like those of D. fusca; found under the stones in cold spirings and streams in the mountains; very agile and not easily caught. 


\section{Family 5 PLEUROderidae \\ Newts}

\section{Diemictylus viridescens, Rafinesque}

Newt, eft

De Kay. Triton millepunctatus, crimson spotted triton, newt, p. 84, pl. 15, fig. 33, 34 .

Brownish olive above; straw-colored or dirty white below; each side with a row of three to six scarlet spots, each with a dark border; very small dots all over. 12 obscure costal furrows. Length $3 \frac{1}{2}$ inches.

Very common in ponds everywhere. The only one of our salamanders which swims around in deep water and does not live on the bottom or under stones. Eggs laid one at a time in the axils of leaves of water plants.

\section{Var. miniatus}

\section{Red eft}

De Kay. Salamandra coccinea, the scarlet salamander, p. 81, pl. 21, fig. $54 \mathrm{~b}$

Very similar, but bright vermilion red; skin rougher. It is found in the same region but away from water; under stones, etc. coming out after rain. Probably a form of the preceding, its peculiarities being due to life out of water.

\section{Order 3 (ANURA) SALIENTIA}

Tailless batrachians

Body short and broad; all four limbs present, the hinder limbs long and strong, adapted for leaping; lower jaw usually toothless; tail wanting in the adult.

The eggs are laid in compact gelatinous masses, usually attached to sticks or weeds, in the water. The young tadpoles have external gills when first hatched, but these are soon covered over by a gill cover, which has a single opening at one side (fig. 4). Both pairs of limbs develop at the same time, but the anterior pair are inclosed in the gill covers and do not break them till a late stage. The tail gradually becomes absorbed, and the gills disappear, while lungs develop, and the animal attains its adult form, which is always froglike and air-breathing. 
Four families: 1 Bufonidae, toads

2 Pelobatidae, burrowing toads

3 Hylidae, tree frogs

4 Ranidae, frogs.

Family 1 BUFONIDAE

Represented by one species.

\section{Bufo lentiginosus (Shaw) \\ Common toad}

De Kay. B u fo a m e ri c a n u s, p. 67 , pl, 19, fig. 46 (young); pl. 20, fig. 52 (adult)

Yellowish brown with a yellow vertebral line and some brownish spots, but variable;-adults very warty; young smooth.

Common everywhere. Their eggs are laid in the spring and are inclosed in a long, thin-walled tube of transparent albuimen, which lies in strings on the bottom of the ponds where they are laid. The young attain the adult form at a very much earlier period of their life than the frogs.

\section{Family 2 PETOBATIDAE Burrowing toads}

Represented by one species.

\section{Scaphiopus holbrookii Harlan}

\section{Spadefoot}

De Kay. S c a p h i o p us s o lit a r i s, the hermit spade foot, p. 66, pl. 19. fig. 47

Olive brown, a yellowish band on each side from eye to coccyx; a horny, spadelike process on each side of hind foot. Widely distributed, but rarely seen. It remains in burrows which it digs in the earth and lays its eggs in temporary ponds which are formed by rain. Metamorphosis may be very rapid.

Reported by De Kay from Rockland county.

\section{Family 3 HYLIDAE Tree frogs}

Small forms, generally inhabiting trees or bushes and frequently possessing the power of adapting their color to the color of the object on which they rest. Generally with the tips of their toes expanded to form disks. Eggs laid in water, in smaller packages than those of the true frogs. 


\section{Chorophilus triseriatus Wied.}

Light, ash colored, with about six dark stripes running back from head; legs blotched; toes without disks Length 1 inch. Found in southern part of state.

\section{Acris gryllus Le Conte Cricket frog}

De Kay. Hylodes gryllus, the cricket Hylodes, p. 70, pl, 22, fig. 61

Hind legs very long; brown or gray above, with a blackish triangle between eyes; borders of this are green and are continued as a band to the end of the body; sides with three oblique bands; has considerable power of changing its color ; ends of toes not expanded. Length $1 \frac{1}{2}$ inches.

Found in southern part of state. Frequents the muddy borders of the water, into which it leaps when alarmed. A very strong leaper and is never found on trees.

\section{Hyla pickeringii Storer "Peeper"}

De Kay. Hy lodes pickeringi, Pickering's tree toad, p. 69, pl. 20, fig. 51

Yellowish or reddish brown with a darker $X$-shaped mark in middle of back, extending in front to eyes and to the sides of the body; below, yellowish white; legs barred transversely; large disks on toes. Length 1 inch.

Probably all over the state. Found in colder upland swamps and meadows in the breeding season. Later, tree toads may be found in low places or on the ground in the woods. Later still, they climb the trees, and their voices are almost the last sound heard in the fall.

\section{Hyla versicolor Le Conte}

De Kay. Hyla versicolor, the northern tree toad, p.71, pl. 21, fig. 53a

Green, gray or brown, varying considerably, as its name indicates, with the color of the object on which it rests; $V$-shaped black blotches on the back; below, white; behind, yellow; skin, warty; large disks. Length 2 inches.

The tree frog par excellence of our state; found on trees and fences; lays its eggs in small packages on blades of grass in the water. 


\section{Family 4 RANIDAE}

\section{Frogs}

Usually fair sized forms; strongly developéd hind legs; hind feet well webbed and no disks on toes; mostly water-inhabiting forms.

\section{Rana virescens Kalm}

De Kay. Rana halecina, the shad fróg. common frog, leopard frog, p.63, pl. 20, fig. 49

Green, with irregular black blotches edged with white; these mostly in two irregular rows on back; legs barred above; belly pale; head rather long. Length $2 \frac{8}{4}$ inches.

Probably the commonest of the frogs; found in moist places and marshes. The first species heard in the spring along with Acris gryllus. Frequently lives in swarms.

26 Rana palustris Le Conte

\section{Pickerel, frog}

De Kay. Rana palustris, p. 62, p1. 22, fig. 60

Light brown with two rows of large, oblong square blotches of dark brown on back, one or two on sides; a brown spot above eye; dark band from nostril to eye; upper jaw white spotted with black. Length 3 inches.

Very widely distributed, from mountains in north of state to salt marshes on coast. Usually found in cold springs and streams, and is seen more frequently than any other frog in the grass.

\section{Rana septentrionalis Baird Northern frog}

Brown or olive, with paler, wormlike markings over the back and legs; sometimes a few dark blotches behind. Length $2 \frac{1}{2}$ inches.

Reported from northern part of the state. An entirely aquatic species.

\section{Rana clamata Daudin}

De Kay. Rana fontinalis, the spring frog, p. 62, pl. '21, fig. 54a

Greenish or brownish, shading anteriorly to a bright green; rounded brown spots all over the back; beneath, grayish white; legs with several transverse bands. Length 3 inches.

Aquatic, hatinting all kinds of waters; lives singly or in pairs. 


\section{Rana catesbiana Shaw Bullfrog}

De Kay. Rana pipiens, p. 60, pl, 19, fig. 48

Greenish of varying shades, with small, faint dark spots above; head usually bright green; lower side silvery white with pale blotches instead of pure white as in R.clamata. Length $5 \div 8$ inches.

The largest of our frogs. Found in larger ponds and streams, specially where there is underbrush.

\section{Rana sylvatica Le Conte}

De Kay. Rana sylvatica, the wood frog, p. 64, pl. 21, fig. 54 (adult); pl. 20, fig. 50 (young)

Pale reddish brown; arms and legs barred above; head small, pointed ; dark brown band from eye to arm. Femnu and tibia about equal and considerably more than half length of body. Length $1 \frac{1}{2}$ inches.

Common in woods. In the highlands of the Hudson it appears about the end of March and lays its eggs in ponds and ditches; then very noisy. Later, in May, it becomes quiet (Mearns).

\section{Rana cantabrigensis Baird}

"Very similar to preceding, but tibia equals one half length of body; a narrow pale line along thighs behind; a dorsal line from snout to arms; back sometimes with dark spots; no outer metatarsal tubercle."

Habits similar to preceding. Probably in northern part of state.

\section{COLLECTING AND PREPARING}

Probably the best way to collect reptiles and batrachians is by shooting them with small shot cartridges in a small rifle or pistol. A shotgun with an "auxiliary barrel" may also be used." Many specimens may be taken by a quick grab with the fingers, but this is not always an agreeable experience for most people. For the Urodela a dip net is very useful, and usually frogs may be taken in that way. For snakes a slip noose of fine wire tiel to the end of

1 These directions are taken almost entirely from the Directions for collecting reptiles and batrachians by Leonhard Stejneger, U. S. nat. mus. Bul. 39. 
a stick may be used, or a forked stick with which to pin the animal to the ground.

If not dead when taken, specimens may be killed by dropping into alcohol. Snakes may be killed by taking them by the end of the tail and giving them a quick snap which will dislocate the vertebrae.

The prepared specimens will keep better if the alcohol is injected into the body cavity with a hypodermic syringe. If this is not at hand, they may be slit open along the ventral side with a sharppointed pair of scissors. In the case of snakes, short slits should be made at intervals. It is well to keep the mouths of specimens open by a wad of cotton or paper; and turtles should have the feet drawn out. Alcohol of the full commercial strength should not be used for preserving. It is much better to put reptiles in alcohol diluted with an equal part of water for the first 24 hours and then into alcohol with one fourth of its volume of water. For batrachians, alcohol even weaker than this should be rused; at first with two thirds water and after 24 hours with one third water.

Labels of strong paper should be attached to the specimen but should never be tied around the neck. For lizards and salamanders, fasten it around the body just behind the fore legs; for frogs and toads, in front of the hind legs; for snakes, around the body at about the anterior third; and for turtles to one of the legs. The labels should be written with a soft lead pencil and should contain : 1) the exact locality where captured;2) the character of the soil and regetation where the specimen was found, whether on sand, among rocks, under logs or stones, in holes, swamp, meadow, forest or any such observations ; 3) date of capture ; 4) collector's name.

After soaking in alcohol for from one to two weeks, according to size, they are ready to be transported. For this purpose, a cigar box, an old tomato can, or, better still, an empty baking powder can, will serve. Take some cotton batting, soak it in alcohol and squeeze it nearly dry; then wrap each individual specimen up and pack solidly in the box or can; when the can is full, add as much alcohol as the contents will hold withont dripping; wrap the parcel in several thicknesses of strong paper, tie securely and forward by mail, if not too large, to the State Museurm, Albany N: Y. 
If there are not enough specimens to fill the can, fill it up with cotton. Do not use glass, as it is liable to break.

Living specimens of any of the forms except the larger turtles would be specially valuable and may safely be sent by express (collect). They are best sent in soft damp moss so as to keep them from jarring.

Notes on the following points are greatly to be desired: the occurrence of species in any locality and the conditions under which they were found; their first appearance in the spring and frequency. of occurrence throughout the summer ; their food and mode of life and their times of breeding and breeding habits.

Any notes or specimens sent to the museum will be acknowledged and full credit given in the Museum reports and any further publications. 


\section{N DEX}

The superior figures tell the exact place on the page in ninths; e. g. $399^{3}$ means page 399, beginning in the third ninth of the page, i. e. about one third of the way down.

Abbot, C. C., cited, 379 ${ }^{9}$

Abdominal plates, defined, $362^{4}$

Acris gryllus, $405^{2}$

Adder, blowing, $368^{1}$

Agkistrodon contortrix, $385^{4}-86^{2}$

Alleghany hellbender, $398^{2}$

Alleghany mountain salamander, $402^{3}$

Allen, Glover M., cited, $384^{8}$

Allen, J. A., cited, $371^{9}$

Amblystoma conspersum, $399^{3}$

jeffersonianum, $399^{7}$

opacum, $398^{7}$

punctatum, $399^{1}$

tigrinum, $399^{5}$

Amblystomidae, $398^{5}-99^{9}$

American naturalist, check list of serpents published in, $\mathbf{c}^{5} \mathrm{~b}^{3}$.

Amphibians, $396^{1}-407^{7}$

Amyda mutica, $392^{2}$

Anal plate, defined, $362^{5}$

Anatomic characters of serpents, $360^{2}$

Ancistrodon, $360^{8}, 365^{2}$

contortrix, $378^{3}, 385^{3}-86^{2}$

piscivorus, $378^{2}$

Anteocular plates, defined, $362^{3}$

Anteorbital plates, defined, $362^{3}$

Anura, $396^{3}, 403^{6}-7^{7}$; anatomy, $403^{7}$; metamorphosis, $403^{8}$; families, $404^{1}$

Aramochelys odorata, $393^{3}$

Aspidonectes spinifer, $392^{3}$

Baird, Spencer $F_{\text {., }}$ cited, $355^{4}, 356^{4}$, $369^{7}$

Banded rattlesnakes, $361^{1}, 387^{3}-88^{9}$

Bascanion constrictor, $370^{6}-71^{4}$

Batrachia, 396 $-407^{7}$; breeding, $396^{5}$; food, $396^{8}$; habitat, $396^{3}$; metamorphosis, $396^{8}$; orders of, $396^{8}$

Batrachians, 389-409; collecting and pireparing, $407^{7}-9^{4}$

tailless, $403^{7}-7^{7}$
Bean, Tarleton, referred to, $383^{6}$

Black snake, $370^{6}-71^{4}$

Blanding's tortoise, $395^{7}$

Blotched salamander, $398^{7}$

Blowing :udder, $368^{1}$

Blue-spotted salamander, $400^{8}-1^{1}$

Blue-tailed lizard, $390^{6}$

Blunt-nosed salamanders, $398^{5}-99^{\circ}$

Box tortoise, $395^{9}$

Box turtle, 3929-935, $395^{9}$

Breeding habits of snakes, $360^{7}$

Brown snake, $380^{7}-81^{3}$

Dekay's, $380^{1}$

Bufo americanus, $404^{3}$

lentiginosus, $404^{3}$

Bufonidae, $404^{2}$

Bullfrog, $407^{1}$

Burrowing toad, $404^{5}$

Calamaria amoena, $366^{7}-67^{2}$

Callopeltis obsoletus, $372^{3}$ vulpinus, 3714-72

Cariuate scales, defined, $362^{6}$

Carphophiops, $360^{9}, 364^{9}$

amoenus, $366^{7}-67^{2}$

Cave salamander, $401^{7}$

Chain snake, $375^{7}-76^{\top}$

Chelonia, $391^{3}-95^{9}$; anatomy, $391^{8}$; breeding, $391^{6}$; families of, $391^{7}$; habitat, $391^{7}$

Chelonura serpentina, $392^{7}$

Chelopus guttatus, $395^{5}$

insculptus, $395^{3}$

muhlenbergii, $395^{2}$

Chelydra serpentina, $392^{6}$

Chelydridae, $392^{5}$

Chorophilus triseriatus, $405^{\mathrm{I}}$

Chrysemys marginata, $394^{9}-95^{1}$

picta, $394^{7}$

Cistudo blandingii, 3957

carolina, $395^{8}$ 
Classification of serpents, $359^{4}-60^{1}$

Clonophis kirtlandi, $379^{6}$

Collecting and preparing reptiles and batrachians, $407^{7}-9^{4}$

Color key to species of serpents, $365^{3}-66^{5}$

Coluber, $360^{8}, 364^{7}$

alleghaniensis, $372^{2}$

constrictor, $370^{6}-71^{4}$

eximius, $374^{7}-75^{4}$

getulus, $375^{8}-76^{7}$

obsoletus obsoletus, $372^{2}$

punctatus, $367^{3}$

verualis, $369^{2}$

vulpinus, $356^{6}, 371^{4}-72^{2}$

Colubridae, $364^{4}, 366^{6}-85^{2}$

Common frog, $406^{2}$

Common lizard, $390^{3}$.

Common toad, $404^{3}$

Cope, Edward D., cited, $359^{7}, 362^{8}, 368^{6}$, $372^{1}, 374^{4}, 374^{5}, 376^{9}, 378^{8}, 379^{5}, 379^{9}$, $383^{3}, 384^{4}, 385^{2}, 387^{1}, 389^{6}, 391^{2}, 398^{9}$ $401^{4}$

Copperhead, $361^{2}, 385^{3}-86^{2}$

Cricket frog, $405^{2}$

Cricket Hylodes, $40 \overline{5}^{3}$

Crimson spotted triton, $399^{2}, 403^{2}$

Crotulidae, $361^{2}, 365^{1}, 385^{2}-88^{9}$

Cro!alophorus tergeminus, $386^{3}-87^{2}$

Crotalus, $360^{8}, 365^{2}$

durissus, $387^{3}-88^{9}$

horridus, $387^{3}-88^{9}$

Cryptobranchidae, $398^{1}$

Cryptobranchus allegheniensis, $398^{2}$

Cyclophis, $360^{8}, 364^{6}$

aestivus, $357^{2}, 369^{8}-70^{5}$

De Kay, James E., cited, 355, $353^{5}$, $359^{6}, 367^{1}, 367^{6}, 368^{6} .369^{5}, 372^{4}, 374^{1}$, $375^{9}, 381^{2}, 385^{8}, 386^{8}, 388^{3}, 389^{3}, 392^{8}$, $394^{2}, 399^{6}, 399^{8}, 401^{8}, 404^{8}$

De Kay's brown suake, $380^{1}$

Desmognathus fusca, $402^{5}$

nigra, $402^{7}$

ochrophaea, $402^{3}$

Diadophis, $360^{9}, 364^{9}$

punctal.us, $367^{3}$

Diamond back, $394^{2}$

Diemictylus viridescens, $403^{2}$
Distribution of serpents, $363^{4}-64^{3}$

Ditmars, Raymond L., cited, $363^{1}, 368^{6}$, $369^{5}, 370^{2}, 375^{1}, 380^{6}, 383^{6}, 385^{8}, 385^{6}$

Dusky garter snake, $384^{3}$

Dusky salamander, $402^{5}$

Dusky triton, $399^{7}$

Eft, $403^{2}, 403^{5}$

Enydidae, $393^{5}-95^{9}$

Emydoidea blandingii, $395^{7}$

Emys geographica, 3937

guttata, $395^{5}$

insculptus, $395^{4}$

muhlenbergii, $395^{2}$

palustris, $394^{3}$

picta, $394^{7}$

pseudogeographicus, $393^{9}-94^{2}$

rubriventris, $394^{4}$

Eumeces quinquelineatus, $390^{6}$

Eutaenia, $360^{8}, 364^{5}$

brachystoma, $382^{1}$

saurita, $381^{4}$

sirtalis, 3631 $382^{4}-83^{1}$

dorsalis, $384^{4}$

graminea, $383^{1}$

obscura, $384^{2}$

ordinata, $383^{3}$

pallidula, $384^{7}-85^{2}$

sirtalis, $383^{7}-84^{2}$

Farr, M. S., referred to, $383^{6}$

Fence lizard, $390^{3}$

Four toed salimander, $400^{2}$

Fox snake, $371^{4}-72^{2}$

Frogs, 406 ${ }^{1}-7^{7}$

cricket, $405^{2}$

tree, $404^{8}-5^{9}$

Frontal plate, defined, $361^{9}-62^{7}$

Garter snake, $362^{8}, 382^{4}-83^{1}$

dusky, $38 x^{3}$

green, $388^{2}$

red, $384^{4}$

spotted, $383^{4}$

striped, $383^{7}-84^{2}$

Gastrosteges, defined, $362^{4}$

Gebhard, John, jr, cited, $356^{5}, 376^{2}, 386^{3}$

Geographic tortoise, $393^{7}$ 
Giant salamander, $398^{1}$

Granulated salaminder, $399^{7}$

Graptemys geographicus, $393^{7}$ pseudogeogriphicus, $393^{9}-94^{2}$

Green garter snake, $383^{2}$

Green suake, rough, $369^{8}-70^{5}$ smooth, $369^{1}$

Ground lizard, $390^{8}-91^{2}$

Gyrinophilus porplayriticus, $401^{2}$

\section{Hellbender, 398"}

Hemidactylium scutatum, $400^{1}$

Hermit spade foot, $404^{6}$

Heterodon, $364^{?}$ platy rhinos, $368^{1}$ platy rhinus, $360^{9}, 363^{2}, 368^{1}$

Holbrook, J. E., cited, $377^{9}, 389^{3}$ Hough, Franklin B., cited, $376^{1}, 376^{3}$ Hyla pickeringii, $405^{5}$ versicolor, $405^{7}$

Hylidae, $404^{8}-5^{9}$

Hylodes gryllus, $405^{3}$ pickeringi, $405^{5}$

Inferior labial plates, defined, $362^{4}$ Internasal plates, defined, $362^{2}$

Jordan, David S., cited; $359^{6}, 364^{4}, 389^{6}$, $394^{6}$

Keeled scales, defined, $362^{6}$

Key to families and genera of snakes, $364^{3}-65^{3}$; to species, $365^{3}-66^{5}$

Kinosternidae, 3929-935

Kinosternun pennsylvanicum, $393^{1}$

Kirtland's suake, $379^{6}$

Labial plates, superior, defined, $362^{3}$; inferior, defined, $362^{4}$

Lacertilia, $390^{1}$

Lampropeltis doliatns, $374^{2}$

triangulus, $374^{8}-75^{4}$

getulus, $375^{5}, 375^{8}-76^{7}$

Large spotted salamander, $399^{2}$

Leather snake, $378^{9}-79^{5}$

Leather turtle, 3922

Liolepisma laterale, $390^{8}-91^{2}$

Leopard frog, $406^{2}$
Leptophis aestivus, $369^{8}-70^{5}$ saurita, $381^{4}$

Liopeltis, $360^{8}, 364^{9}$

vernalis, $369^{1}$

Lizards, 389-409

Long-tailed salamander, $401^{\tau}$

Loreal plates, defined, $362^{3}$

Macauley, James, cited, $387^{2}, 387^{8}$

MacKay, A. II., cited, $369^{7}$

Malnclemmys centrata, $394^{2}$

Map turtle, $393^{7}$

Massasauga, $361^{2}, 386^{3}-87^{2}$

Menrns, Edgar A., cited, $363^{7}, 367^{7}, 368^{7}$, $369^{6}, 371^{2}, 372^{5}, 37.5^{1}, 378^{3}, 381^{2}, 381^{8}$, $38 \overline{0}^{9}, 388^{6}, 398^{9}, 407^{-5}$

Melnnism, $363^{3}, 368^{5}$

Menobrinchus lateralis, $397^{3}$

Inenopoin $\iota$ alleghaniensis, $398^{2}$

Nilk snalie, $362^{8}, 374^{5}, 374^{7}-75^{5}$

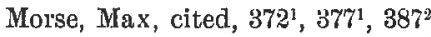

Mud puppy, $397^{3}$

Mud tortoise, $393^{1}$

Mud turtle, $394^{7}$

Muhlenberg's tor toise, $395^{2}$

Musk turtle, $393^{3}$

Nasal plates, defined, $362^{\circ}$

Natrix, $360^{8}, 364^{7}$

fasciatr, $363^{2}, 376^{8}-77^{4}$

ery throgaster, $356^{9}, 377^{1}$

sipedon, $363^{4}, 377^{4-78^{5}}$

kirtlundii, $379^{6}$

leberis, $378^{8}-69^{5}$

rigida, $378^{5}$

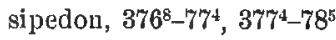

Necturus, $396^{\mathrm{a}}$ maculatus, $39 i^{3}$

Nelson, Julius, cited, $379^{9}$

Newts, $403^{1}$

Nomenclature of serpents, $359^{4}-60^{1}$; of scales, $361^{9}-62^{6}$

Nonvenomous suakes, $360^{1}$

Northern frog, $406^{7}$

Northern rattlesnake, $361^{1}$

Northern tree toad, $405^{8}$

Occipital plates, defined, $362^{2}$

Opheodrys aestivus, $369^{8}-70^{5}$ 
Ophibolus, $360^{8}, 364^{8}$

getulus, $375^{5}$

$$
\text { getulus, } 375^{7}-76^{7}
$$

Osceola, $360^{8}, 364^{8}$

doliata, $356^{8}, 361^{1}, 374^{2}$

clerica, $374^{5}$

triangult, $356^{8}, 374^{5}, 374^{7}-75^{4}$

Oviparous serpents, $360^{7}$

Ovoviviparous serpents, $360^{7}$

Painted turtle, $394^{7}$

Peeper, $405^{5}$

Pelobatidae, $404^{5}$

Pickerel frog, $406^{4}$

Pickering's tree tond, $405^{5}$

Pine lizard, $390^{3}$

Pine snake, 3731-742

Pit-vipers, $361^{2}$

Pituophis melanoleucus, $373^{2}-74^{2}$

Pityophis, $360^{9}, 364^{6}$

melanuleucus, $357^{2}, 373^{1}-74^{2}$

Plethodon cinereus, $400^{4}$

cinereus, $400^{4}$

dorsalis, $400^{6}$

ery thronotus, $400^{5}$

glutinosus, $400^{8}-1^{1}$

Plethodontidae, $400^{1}-2^{9}$

Pleurodelidre, 403'

Pond turtles, $393^{6}-95^{9}$

Postocular p'ates, defined, $362^{2}$

Postorbital plates, defined, $362^{3}$

Prairie rattlesnake, $361^{2}$

Prefrontal plates, defined, $362^{1}$

Preocular plates, defined, $362^{3}$

Proteîda, 3962 3 3 $^{11}$

Proteidae, 397"

Pseudemys hierogly phica, $394^{6}$

rubriventris, $394^{4}$

Pscudogeographic tortoise, $393^{9}-94^{2}$

\section{Racer, 372 2}

Rana cantabrigensis, $407^{6}$

catesbiann, $40^{12}$

clamata, $406^{8}$

fontinalis, $406^{8}$

halecina, $406^{2}$

palustris, $406^{4}$
Rana pipiens, $407^{2}$

septentrionalis, $406^{7}$

sylvatica, $407^{3}$

virescens, $406^{2}$

Ranidae, $406^{1}-7^{7}$

Rattlesuake, banded or northern, $361^{1}$, $387^{3}-88^{9}$

prairie, $361^{2}$

Rẹd-backed salamander, $400^{4}$

Red-bellied terrapin, $394^{4}$

Red eft, $403^{5}$

Red garter snake, $384^{4}$

Red salamander, $401^{9}-2^{2}$

Reed, H. D., acknowledgments to, $356^{9}$, $357^{1}$; cited, $363^{8}, 367^{7}, 369^{6}, 371^{3}, 372^{9}$, $375^{4}, 378^{4}, 381^{3}, 381^{9}, 391^{4}$

Reference list, $357^{3}-59^{8}$

Regina leberis, $378^{9}-79^{5}$ rigida, $378^{6}$

Reptiles, breeding habits, $360^{7}$; collecting and preparing, 4077-94

Ribbon snake, $381^{4}$

Ring-necked snake, $367^{3}$

Rockland county, suakes of, $363^{8}$

Rostral plate, defined, $362^{2}$

Rough green snake, $369^{8}-70^{5}$

Salamanders, $397^{6}-403^{6}$

Salamandra bilineata, $401^{4}$

coccinea, $408^{5}$

ery thronota, $400^{4}$

fasciata, $398^{3}$

glutinosa, $400^{8}-1^{1}$

granulata, $399^{7}$

longicauda, $401^{7}$

picta, $402^{5}$

rubra, $401^{9}-2^{2}$

salmonea, $401^{2}$

subviolacen, $399^{2}$

Salientia, $396^{3}, 40 e^{6}-7^{7}$

Salmon-colored salamander, $401^{2}$

Salt marsh turtle, $394^{2}$

Salt water terrapin, $394^{3}$

Scales, nomenclature, $361^{9}-62^{6}$

Scaphiopus holbrookii, $404^{6}$

solitarius, $404^{6}$

Scarlet salamander, $405^{5}$

Sceloporus undulatus, $390^{8}$ 
Scincus fasciatus, $390^{6}$

Scorpion, $390^{6}$

Serpents of the northeastern United States, 356-88

Shad frog, $406^{2}$

Sherwood, W. L., cited, $389^{4}$

Sistrurus, $360^{8}, 365^{2}$

catenatus catenatus, $356^{5}, 386^{3}-87^{2}$

Slider; $394^{4}$

Smaller spotted salamander, $3 \$ 9^{3}$

Smitle, W. H., cited, $376^{9}, 387^{1}, 389^{4}$, $400^{8}, 401^{8}$

Smooth green snake, $369^{1}$

Suqkes, breeding habits, $360^{7}$; collecting and preparing, $407^{7}-9^{4}$

Snapping turtles, $392^{\circ}$

Soft-shelled turtles, $391^{9}-92^{5}$, $393^{4}$

Southern tier, no records, $364^{1}$

Southwick, E. B., cited, $388^{6}$

Spadefoot. $404^{6}$

Speckled tortoise, $395^{5}$

Spelerpes bilineatus, $401^{4}$

longicauda, $401^{6}$

ruber, $401^{9}-2^{2}$

Spotted garter suake, $383^{4}$

Spotted sulamander, $399^{1}$

Spotted tortoise, $395^{5}$

Spring frog, $406^{8}$

Stejneger, Lconhard, cited, $361^{6}$, 3772, $407^{9}$

Sternothaerus odoratus, $393^{4}$

Stiff snake, $378^{5}$

Stink pot, $393^{8}$

Storeria, $360^{8}, 364^{6}$

dekcayi, $380^{1}, 380^{2}$

occipitomaculata, $356^{5}, 380^{7}-81^{3}$

Striped-back salamander, $401^{4}$

Striped g rter snake, $383^{7}-84^{2}$

Subcrudal plates, defined, $362^{5}$

Superciliary plates, defined, $362^{1}$

Sụperior labial platés, defined, $362^{3}$

Swift lizard, $390^{3}$

Temporal plates, defined, $362^{4}$

Teriry, W. J., cited, $391^{2}$

Thamnophis sauritus, $381^{4}$

sirtalis, $3 \times 2^{i}-83^{1}$

dorsalis, $384^{5}$

ordinatus, $383^{4}$
Tiger salam:tnder, $399^{5}$

Tond, burrowing, $404^{5}$

common, $404^{2}$

northern tree, $405^{8}$

Pickering's tree, $405^{5}$

tree, $405^{5}, 405^{8}$

Tortoises, 389-409, 3913 $-95^{9}$

Tree frogs, $404^{8}-5^{9}$

Tree toad, northern, $405^{8}$

Pickering's, $405^{5}$

Trigonocephalus contortrix, $385^{4}-86^{2}$

Triony chidae, $391^{1}-92^{5}$

Trionyx ferox, $392^{4}$

Triton, $399^{5}$

crimson spotted, $399^{2}, 403^{2}$

dusky, $399^{7}$

Triton millepunctatus, $403^{2}$

niger, $399^{\urcorner}$

tigrinus, $399^{5}$

Tropidolepis undulatus, $390^{4}$

Tropidonotus dekayi, $380^{1}$

leberis, $378^{9}-79^{5}$

niger, $377^{9}$

rigidus, $37 t^{5}$

sipedon, $377^{4}-78^{5}$

trenia, $382^{\sharp}-83^{1}$

Turtles, $391^{3}-95^{9}$

Urodela, $396^{3}, 397^{6}-403^{6}$; metamorphosis, $397^{6}$; families, $397^{8}$

Urosteges, defined, $362^{5}$

Variation in animals, $362^{7}-63^{4}$; of Eutaenia sirtalis, $382^{7}$; of Osceola doliata, $374^{4}$

Venomous snakes, $361^{1}$

Vertical plate, defined, $361^{9}-62^{7}$

Wallace, W. Seward, acknowledgments to, $356^{9}$, $357^{9}$; cited, $363^{9}, 367^{1}$, $367^{3}, 368^{7}, 369^{7}, 370^{2}, 371^{4}, 372^{6}, 373^{9}$, $375^{5}, 378^{5}, 380^{7}, 381^{3}, 381^{9}, 383^{6}, 386^{1}$

Water suake, $377^{4}-78^{5}$

Wood frog, $407^{4}$

Wood terrapin, $395^{4}$

Wood tortoise, $395^{4}$

Worm snake, $366^{7}-67^{2}$

Zamenis, $360^{8}, 364^{9}$

constrictor, $370^{6}-71^{4}$ 


\section{University of the State of New York}

\section{Neze York State Museum}

\section{MUSEUM PUBLICATIONS}

Any of the University publications will be sold in lots of ro or more at $20 \%$ discount. When sale copies are exhausted, the price for the few reserve copies is advanced to that charged by secondhand booksellers to limit their distribution to cases of special need. Such prices are inclosed in brackets.

All publications are in paper covers, unless binding is specified.

Museum annual reports $\times 847$-date. All in print to $1892,50 \mathrm{a}$ volume, $75 \mathrm{c}$ in cloth; 1892-date, 75c, cloth.

These reports are made up of the reports of the director, geologist, paleontologist, botanist and entomologist, and museum bulletins aud memoirs, issued as advance sections of the reports.

Geologist's annual reports I88I-date. Rep'ts I, 3-13, I7-date, O. ; 2, 14-16, Q.

The annual reports of the ear] y natural history survey, 1836-42 are out of print.

Reports 1-4, 1881-84 were published only in separate form. Of the 5th report 4 pages were reprinted in the 39 th unseum report, and a supplement to the 6 th report was included in the 40 th museum report. The 7 th and subsequent reports are inclurled in the 41st aud following musenm reports, except that certain Jithograplic plates in the 11 th report (1891), 13th (1893) are omitted from the 45th and 47 th museum reports.

Separite volumes of the following only are available.

$\begin{array}{llcccc}\text { Report } & \text { Price } & \text { Report } & \text { Price } & \text { Report } & \text { Price } \\ 12(1892) & \$ .50 & 16 & \$ 1 & 19 & \$ .40 \\ 14 & .75 & 17 & .75 & 20 & \text { In press } \\ 15 & 1 & 18 & .75 & & \end{array}$

In 1898 the paleontologic work of the state was made distinet from the geologic and will hereaf ter be reported separately.

Paleontologist's annual reports r899-date.

See fourth vote under Geologist's reports.

Bound also with wuseum reports of which they form a part. .Reports for 1899 and 1900 may be had for 20c each. Beginning with 1901 these reports will be issued as bulletins.

Botanist's annual reports 1869 -date.

Bound also with museum reports 22-date of which they form a part; the first botauist's report appeared in the $22 \mathrm{~d}$ museum report and is numbered 22 .

Reports 22-11, 48, 49, 50 and 52 (Museuı bulletin 25) are out of print ; $42-47$ are inaccessible. Report 51 may be had for $40 \mathrm{c} ; 53$ for $20 \mathrm{c} ; 54$ for $50 \mathrm{c}$. Beginning with 1901 these reports will be issued as bulletins.

Deseriptions and illustrations of edible, poisonous and nuwholesome fungi of New York have been published in volumes 1 and 3 of the 48 th museum report and in volume 1 of the $49 \mathrm{tb}$, 51st and 52d reports. The botanical part of the 51st is available also in separate form. The descriptious aud illustrations of edible and unwholegome species contained in the $49 \mathrm{th}$, 51st and $52 d$ reports have been revised and rearrauged, and combined with others more recently prepared and constitute Mnseum memoir 4.

Entomologist's annual reports on the injurious and other insects of the State of New York 1882-date.

Bound also with nusenm reports of which they form a part. Beginning with 1898 these reports have been issued as bulletins. Reports 3-4 are out of print, other reports with prices are:

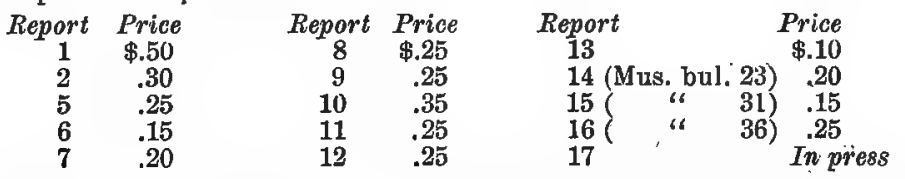

Reports 2, 8-12 may also be obtained bound separately in cloth at 25c in addition to the price given above. 
Museum bulletins I887-date. O. To advance subscribers, $\$ 2$ a year or $50 \mathrm{C}$ a year for those of any one division: (1) gealogy, including zoology, archeology and mineralogy, (2) paleontology, (3) botany, (4) - entomology.

Beginning with bulletin 12 bulletins are also found with the annual reports of the museum as follows:

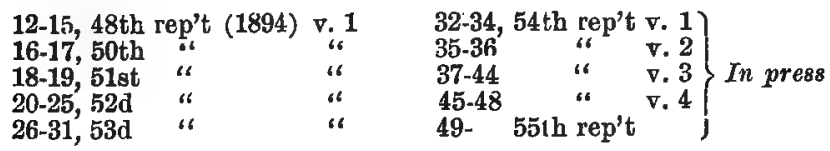

Volume r. 6 nos. \$r.50 in cloth

I Marshall, W: B. Preliminary List of New York Unionidae. 2op. Mar. I892. 5c.

2 Peck, C: H. Contributions to the Botany of the State of New York. 66p. 2pi.. May 1887 . [35c]

3 Smock, J: C. Building Stone in the State of New York. r52p. Mar. 1888. Out of print.

4 Nason, F. L. Some New York Minerals and their Localities. 2op. rpl. Aug. 1888. 5c.

5 Lintner, J. A. White Grub of the May Beetle. 32p. il. Nov. I888. IOc. 6 - Cut-worms. 36p. il. Nov. 1888. IOC.

\section{- Volume 2. 4 nos. [\$1.50] in cloth}

7 Smock, J: C. First Report on the Iron Mines and Iron Ore Districts in New York. $6+7$ op. map $58 \times 60 \mathrm{~cm}$. June $\mathrm{r} 889$. Out of print.

8 Peck, C: H. Boleti of the United States. 96p. Sep. r889. [5OC]

9 Marshall, W: B. Beaks of Unionidae inhabiting the Vicinity of Albany, N. Y. 24p. rpl. Aug. 1890. TOC.

ro Smock, J: C. Building Stone in New York. 2 rop. map $58 \times 60 \mathrm{~cm}$. tab. Sep. $1890,40 c$.

\section{Volume 3. 5 nos.}

II Merrill, F: J. H. Salt and Gypsum Industries in New York. 92p. r2pl. 2 maps $38 \times 5^{8}, 6$ Ix66 $\mathrm{cm}$, I I tab. Ap. I893. $40 c$.

12 Ries, Heinrich. Clay Industries of New York. 174p. 2pl. map $59 \times 67 \mathrm{~cm}$. Mar. 1895. 300 .

I3 Lintner, J. A. Some destructive Insects of New York State; San José Scale. 54p. 7pl. Ap. 1895. 15 c.

I4 Kemp, J. F. Geology of Moriah and Westport Townships, Essex co. N. Y., with Notes on the Iron Mines. $3^{8 p}$. 7 pl. 2 maps $30 \times 33,3^{8 \times 44}$ cm. Sep. 1895. IOC.

I5 Merrill, F: J. H. Mineral Resources of New York. 224p. 2 maps $23 \times 36,59 \times 67 \mathrm{~cm}$. Sep. 1895 . 40 .

\section{Volume 4}

I6 Beauchamp, W: M. Aboriginal chipped Stone Implements of New York. 86p. 23pl. Oct. 1897. $25 c$.

I7 Merrill, F: J. H. Road Materials and Road Building in New York. 52 . 14pl. 2 maps $34 \times 45,68 \times 92 \mathrm{~cm}$. Oct. 1897. I5C. Maps separate roc each, two for 150 .

I8 Beauchamp, W: M. Polished Stone Articles used by the New York Aborigines. 104p. $35 \mathrm{pl}$. Nov. 1897 . 25c. 
I9 Merrill, F: J. H. Guide to the Study of the geological Collections of the New York State Museum. I62p. I I gpl. map $33 \times 43 \mathrm{~cm}$. Nov. I898. $40 c$.

\section{Volume 5}

20 Felt, E. P. Elm-leaf Beetle in New York State. 46p. il. 5pl. June 1898 . $5 c$.

2I Kemp, J. F. Geology of the Lake Placid Region. 24p. Ipl. map $33 \times 34 \mathrm{~cm}$. Sep. 1898 . 5 c.

22 Beauchamp, W: M. Earthenware of the New York Aborigines. 78 p. 33pl. Oct. I 898 . $25 c$.

23 Felt, E. P. 1 4th Report of the State Entomologist I8g8. r $5 \%$. il. 9pl. Dec. I898. $20 c$.

24 Memorial of the Life and entomologic Work of J. A. Lintner Ph.D. State Entomologist $1874-98$; Index to Entomologist's. Reports I-r 3. 3 I6p. rpl. Oct. 1899. 35c. Supplement to 14th report of the state entomoloyist.

25 Peck, C: H. Report of the State Botanist 1898. 76p. 5pl. Oct. I899. Out of print.

\section{Volume 6}

26 Felt, E. P. Collection, Preservation and Distribution of New York Insects. $36 \mathrm{p}$. il. Ap. 1899 . $5 \mathrm{c}$.

27 Shade-tree Pests in New York State. 26p. il. 5 pl. May I899. $5 c$.

28 Peck, C: H. Plants of North Elba. 206p. map I2xi6cm. June 1899. 20c.

29 Miller, G. S. jr. Preliminary List of New York Mammals. r24p. Oct. 1899 . $15 c$.

30 Orton, Edward. Petroleum and natural Gas in New York. $136 \mathrm{p}$. il. 3 maps $13 \times 23,7 \times 22,9 \times 14 \mathrm{~cm}$. Nov. 1899 . $15 \mathrm{c}$.

3I Felt, E. P. I 5 th Report of the State Entomologist I89g. I $28 \mathrm{p}$. June 1900. $15 c$.

\section{Volume 7}

32 Beauchamp, W: M. Aboriginal Occupation of New York. Igop. I6pl. 2 maps $44 \times 35,93.5 \times 69.5 \mathrm{~cm}$. Mar. 1900 . 306 .

33 Farr, M. S. Check List of New York Birds. 224p. Ap. 1900. 25 c.

34 Cumings, E. R. Lower Silurian System of eastern Montgomery County; Prosser, C: S. Notes on the Stratigraphy of Mohawk Valley and Saratoga County, N. Y. 74p. ropl. map 32.5x44cm. May 1900. '15c.

35 Ries, Heinrich. Clays of New York: their Properties and Uses.

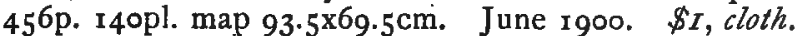

36 Felt, E. P. I6th Report of the State Entomologist rgoo. I 18p. I6pl. Mar. Ig0I. $25 c$.

Volume 8

37 Catalogue of Some of the more important Injurious and Beneficial Insects of New York State. 54p. il. Sep. Igoo. IOC.

38 Miller, G. S. jr. Key to the Land Mammals of northeast. North America. 106p. Oct. I900. $15 \mathrm{c}$.

39 Clarke, J: M ; Simpson, G: B. \& Loomis, F: B. Paleontologic Papers r. 72 p. il. 16pl. Oct. 1900. 15 c.

Contents: Clarke, J: M. A remarkable Occurrence of Orthoceras in the Oneouta Beds of the Chenango Valley, N. Y.

- Paropsonema Cryptophya; a peculiar Echinoderm from the Int umescenszone (Portage Beds) of western New York.

Dictyonine Hexactinellid Sponges from the Upper Devonic of New York.

The Water Biscuit of Squaw Igland, Canandaigua Lake, N. Y. 
Simpson, G: B. Preliminary Descriptious of new Gevera of Paleozoic Rugob. Corals.

Loomis, F; B. Siluric Fungi from western New York.

40 Simpson,'G: B. Anatomy and Physiology of Polygyra Albolabris and Limax Maximus and Embryology of Limax Maximus. $82 \mathrm{p} .28 \mathrm{pl}$. Oct. I90I. $25^{\circ}$.

$4 I$ Beauchamp, W: M. Wampum and Shell Articles used by New York Indians. 166p. 28pl. Mar. I90r. 306.

42 Ruedemann, Rudolf. Hudson River Beds near Albany and their taxonomic Equivalents. I I4p. 2pl. map 24.5x51.5cm. Ap. rgor. $25 c$.

43 Kellogg, J. L.' Clam and Scallop Industries of New York. $3^{6 p}$. 2 p!. map 25.5 $11.5 \mathrm{~cm}$. Ap. I901. IOC.

44 Ries, Heinrich. Lime and Cement Industries of New York. In press. Lekel, E. C. Chapters on the Cement Industry.

\section{Volume 9}

45 Grabau, A. W. Geology and Paleontology of Niagara Falls and Vicinity. 286p. il. 18pl. map $38 \times 84.5 \mathrm{~cm}$. Ap. I gor. 65c; cloth goc.

46 Felt, E. P. Scale Insects of Importance and a List of the Species in New York. 94p. il. r 5pl. June rgor. $25 \mathrm{c}$.

47 Needham, J. G. \& Betten, Cornelius. Aquatic Insects in the Adirondacks. 234p. il. $36 \mathrm{pl}$. Sep. Igor. $40 \mathrm{c}$.

48 Woodworth, J. B. Pleistocene Geology of Nassau County and Borough of Queens. $58 \mathrm{p}$. il. 9pl. map $35^{\times} 7 \mathrm{Icm}$. Dec. 1901. $25 \mathrm{c}$.

Volume ro

49 Ruedemann, Rudolf; Clarke, J: M. \& Wood, Elvira. Paleontologic. Papers 2. 24\%p. 13pl. Dec. I901. 40C.

Contents: Ruedemann, Rudolf. Trenton Couglomerate of Rysedorph Hill.

Clarke, J: M. Limestones of central and western New York Interbedded with bituminous Shales of the Marcellus Stage.

Wood, Elvira. Marcellus Limestones of Lancaster, Erie Co. N. Y.

Clarke, J: M. New Agelacrinites.

Valne of Amnigenia as an Indicator of fresh-water Deposits during the Devonic of New York. Ireland and the Rhineland.

50 Beauchamp, W: M. Horn and Bone Implements of the New York Indians. I I 2p. 43pl. Mar. I9o2. 306.

5 I Eckel, E. C. \& Paulmier, F. C. Catalogue of Reptiles and Batrachians of New York. 64p. il. Ipl. Ap. I902. $15 \mathrm{c}$.

Eckel, E. C. Serpents of uortheastern Uvited States.

Paulmier, F. C. Ijizards, Toltoises and Batrachians of New York.

52 Clarke, J: M. Report of the State Paleontologist 19or. In press.

Felt, E. P. 17th Report of the State Entomologist I9o1. In press. Merrill, F: J. H. Directory of Natural History Museums in United States and Canada. In press.

Peck, C: H. Report of the State Botanist I9or. In press. Merrill, F: J. H. Geologic Map of New York. In preparation. Bean, T. H. Catalogue of the Fishes of New York. In press. Dickinson, H. T. Bluestone Quarries in New York. In press. Beauchamp, W: M. Metallic Implements of the New York Indians. In press.

Whitlock, H. P. Guide to the Mineral Collections of the New York State Museum. In press.

Clarke, J : M. \& Ruedemann, Rudolf. The Guelph Formation and Fauna of western New York.' In preparation.

Clarke, J: M. Catalogue of Type Specimens of Paleozoic Fossils in the New York State Museum. In press. 


\section{University of the State of New York}

MUSEUM PUBLICATIONS (continued)

\section{Museum memoirs r889-date. $Q$.}

I Beecher, C: E. \& Clarke, J: M. Development of some Silurian Brachiopoda. 96p. 8pl. Oct. 1889 . Out of print.

2 Hall, James \& Clarke, J: M. Paleozoic Reticulate Sponges. 35op. il. 7opl. Oct. $1899 . \$ \$ 1$, cloth.

3 Clarke, J: M. The Oriskany Fauna of Becraft Mountain, Columbia Co. N. Y. I28p. 9pl. Oct. I900.' 8oc.

$\$ 4$ Peck, C: H. N. Y. edible Fungi, I895-99. Io6p. 25 pl. Nov. 1900. 75 c. This includes revised deseriptions and illustrations of fungi reported in the 49th, 51st and 52d reports of the state botanist.

Natural history of New York. 3ov. il. pl.maps. Q. Albany 1842-94.

DIVISION 1 zoologY. De Kay, James E. Zoologs of New York; or, The New York Fanna, comprising detailed Descriptions of all the Animals hitherto observed within the State of New York with brief Notices of those oceasionally found near its Borders, and accompanied by appropriate Illustrations. 5 vं. sil. pl. maps. sq. Q. Albany 1812-44. Out of print.

Historlcal introduction to the serles by Gov. W: H. Seward, 178p.

v. 1 pt1 Mammatia. 13+146p. 33pla 1842,

300 coples with hañd-colored plates.

v. 2 pt2 Birds. 12+380p. 141pl. 1844. Colored plates.

v. 3 pt3 Reptiles and Amphibia. 7+98p. pt4 Fishes. 15+415p. 1842. pt3-4 bound together.

v.4 Plates to accompany v. 3. Reptiles and Amphibia 23pl. Fisbes 79pl. 1843. 300 coples with hand-colored plates.

v. 5 pt5 Mollusea. 4+271p. 40pl. pt6 Crustacea. 70p. 13pl. 1813-44. Hand-colored plates: pt5-6 bound together.

DIVISION 2 вотANY. Torrey, John. Flora of the State of New York; comprising full Deseriptious of all the indigenous and naturalized Plants hitherto discovered in the State, with Remarks on their economical and medical Properties. 2v. il. pl. sq. Q. Albauy 1843. Out of print.

v. 1 Flora of the State of New York. $12+484 \mathrm{p}, 72 \mathrm{pl} .1843$. 300 copies with hand-colored plates.

v. 2 Flora of the State of New York. 572p. 89pl. 1843. 300 coples with hand-colored plates.

Division 3 mineralogy. Beck, Lewis C. Mineralogy of New York; comprising detailed Descriptions of the Minerals hitherto found in the State of New York, and Notices of their Uses in the Arts and Agriculture. il. pl. sq. Q. Albany 1842. Out of print.

v. 1 pt1 Economical Mineralogy. pt2 Descriptive Mineralogy. 24+536p. 1842 . 8. plates additional to those printed as part of the text.

Division 4 GEOLOGY. Mather, W : W.; Emmons, Ebenezer; Vanuxem, Lardner \& Hall, James. Geology of New York. 4v. il. pl. sq. Q. Albauy 1842-43. Out of print.

v. 1 pt1 Mather, W: W. First geological District. $37+653 \mathrm{p} .46 \mathrm{pl} .1843$.

$\checkmark .2$ pt2 Emmons, Ebenezer. Second geological District. $10+437 \mathrm{p} .17 \mathrm{pl} .1842$.

v. 3 pt3 Vannxem, Lardner. Third geologioal District. 306p. 1842.

v. 4 pt4 Hall, James. Fourth geological District. 22+683p. Map and 19pl. 1843.

Division 5 agriculture. Emmons, Ebenezer. Agriculture of New York; comprising an Account of the Classification, Composition and Distribution of the Soils and Rocks aud the natural Waters of the different geological Formations, together with a condensed View of the Meteorology and agricultural Productions of the State. 5v. il. pl. sq. Q. Albany 1846-54. Out of print.

จ. 1 Soils of the State, their Composition aud Distribution. 11+371p. 21pl. 1846.

. 2 Analyses of Soils, Plants, Oereals, etc. $8+343+46 p .42 p 1.1849$. With hand-colored plates. 
v. 3 Fruits, etc. $8+340$ p. $185 i$.

v. 4 Plates to accompany v. 3. 95pl. 1851. Hand-colored.

v. 5 Insects Injurious to Agriculture. 8+272p. 50pl. 1854. With hand-colored plates.

division 6 Palnontology. Hall, James. Paleontology of New York. 8v. il. pl. sq. Q. Albany 1847-94. Bound in cioth.

v. 1 Organic Remains of the lower Division of the New York System. 23+338p. 99pl. 1847. Out of print.

$\checkmark .2$ Organic Remains of lower Middle Division of the New York System. $8+362$ p. 104pl. 1852. Out of print.

v. 3 Organic Rewans of the Iower Helderberg Group and the Oriskany Sandstone. pt1, text. $12+532$ p. 1859. [\$3.50].

- pt2, 143pl. 1861. \$2.50.

v. 4 Fossil Brachiopoda of the upper Helderberg, Hamilton, Portage and Chemung Groups. $11+1+428 \mathrm{p} .99 \mathrm{pl}$. 1867. \$2.5o.

\. 5 pt1 Lamellibranchiata 1. Monomyaria of the upper Helderberg, Hamilton and Chemung Groups. $18+268 \mathrm{p} .45 \mathrm{pl}$. 1884. $\$ 2.50$.

- Lamellibranchiata 2. Dimyaria of the npper Helderberg, Hamilton, Portage and Chemung Groups. 62+293p. 51pl. 1885 . $\$ 2.50$.

- pt2 Gasteropoda, Pteropoda and Cephalopoda of the upper Helderberg, Hamilton, Portage and Chemung Groups. 2v. 1879. v. 1, text: 15+492p. v. 2, 120pl, \$2.5o for $z$ v.

v. 6 Corals and Bryozoa of the lower and upper Helderberg and Hamilton Groups. 24+298p.67pl. 1887. \$2.50.

v. 7 Trilobites and other Crustacea of the Oriskany; upper Helderberg, Hamilton, Portage, Chemung and Catskill Groups. 64+236p. 46pl. 1888. Cont. supplement to $\nabla .5$, pt2. Pteropoda, Cephalopoda and Annelida. 42p. 18pl. 1888. $\$ 2.50$.

v. 8 pt1 Introduction to the Study of the Genera of the Paleozoic Brachiopoda. 16+367p. 44 pl. 1892 . \$2.50.

- pt2 Paleozoio Brachiopoda. $16+394$ p. 84pl. 1894. $\$ 2.50$.

Museum handbooks 1893 -date. $7 \mathrm{I} / 2 \times 12 \mathrm{r} / 2 \mathrm{~cm}$.

In quantities, 1 cent for each 16 pages or less. Single copies postpaid as below.

H5 New York State Museum. r4p. il. $3 c$.

Outlines bistory and work of the museum; with list of staff and scientifis publications, 1893.

HI3 "Paleontology. $8 \mathrm{p}: 2 \epsilon$.

Brief outline of State Musenm work in paleontology under heads : Definition; Relation to biology; Relation to stratigraphy; History of paleontology in New
York.

HI5 Guide to Excursions in the fossiliferous Rocks of New York. I 2 op. $8 c$.

Itineraries of 32 trips covering nearly the entire series of paleozoio rooks, pre: pared specially for the use of teachers and students desiring to acquaiut themselves more intimately with the classic rocks of this state.

Hi6 Entomology. 8p. Out of print.

Hr7 Geology. In preparation.

Maps. Merrill, F: J. H. Economic and geologic Map of the State of 'New York. $59 \times 67 \mathrm{~cm}$. 1894 . "Out of print:

Scale 14 miles to 1 inch. New edition in preparation.

Printed also with Museum bulletin 15 and the 48 th museum report, $v .1$. Geologic Map of New York. 1901. \$. Mounted on rollers $\$ 5$.

Seale 5 miles to 1 inch. 


\section{CONSERVATION}

REVIEW : 3-28-9.. 
